\title{
Ernstbrunn Limestone and Klentnice beds (Kimmeridgian-Berriasian; Waschberg-Ždánice Unit; NE Austria and SE Czech Republic): state of the art and bibliography
}

\author{
SiMON SCHNEIDER, MATHIAS HARZHAUSER, ANDREAS KROH, AlEXANDER LUKENEDER \\ \& MARTIN ZUSCHIN
}

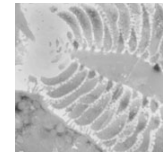

\begin{abstract}
This paper summarises the knowledge of the Ernstbrunn Limestone and Klentnice beds and provides a comprehensive scientific bibliography on these strata. At outcrop both lithostratigraphic units occur as so-called "tectonic klippen" inserted in the autochthonous sedimentary succession of the Waschberg-Ždánice Unit. The latter is a distal, transitional Alpine-Carpathian tectonic nappe that extends between the Danube and Thaya rivers in Lower Austria and southern Moravia. Both strata have also been identified from several drillings and belong to the autochthonous Mesozoic succession deposited on the southern slope of the Bohemian Massif. Ammonite biostratigraphy and micropalaeontology reveal a Kimmeridgian to early Late Tithonian age for the Klentnice beds and a Middle Tithonian to Berriasian (?Hauterivian) age for the Ernstbrunn Limestone. The Ernstbrunn-Pavlov Carbonate Platform gradually developed from the Klentnice beds and persisted during the Jurassic-Cretaceous transition. The rock record provides evidence for lagoonal and patch reef facies and fringing ooid-oncoid bars, all attributed to the Ernstbrunn Limestone. The gradual transition to more distal, siliciclastically-influenced settings is formed by the upper portion of the Klentnice beds that developed as lateral equivalents of the carbonates. In places, both strata are highly fossiliferous. The lagoonal limestones preserve a megadiverse, mollusc-dominated assemblage of more than 500 species of invertebrates and calcareous algae. Most abundant taxa include Heterodiceras and Epidiceras bivalves (basal rudists), nerineid gastropods, decapods, ammonites, corals, and dasycladaceans. As a result of diagenetic aragonite loss, the fauna of the Klentnice beds appears impoverished and is dominated by echinoderms, calcareous sponges, and brachiopods. A remarkably large portion of the complex depositional and natural environment of the Ernstbrunn Limestone and Klentnice beds is preserved both at outcrop and in subsurface and still awaits systematic scientific effort in various fields. Key words: tectonics, stratigraphy, Tithonian-Berriasian, Upper Jurassic-Lower Cretaceous, northern Tethys margin, carbonate platform.
\end{abstract}

SCHNEIDER, S., HARZHAuser, M., KroH, A., LuKEneder, A. \& ZuSChin, M. 2013. Ernstbrunn Limestone and Klentnice beds (Kimmeridgian-Berriasian; Waschberg-Ždánice Unit; NE Austria and SE Czech Republic): state of the art and bibliography. Bulletin of Geosciences 88(1), 105-130 (9 figures, 1 table). Czech Geological Survey, Prague. ISSN 1214-1119. Manuscript received April 17, 2012; accepted in revised form July 12, 2012; published online November 23, 2012; issued December 6, 2012.

Simon Schneider (corresponding author), Mathias Harzhauser, Andreas Kroh \& Alexander Lukeneder, Natural History Museum Vienna, Department of Geology \& Palaeontology, Burgring 7, 1010 Vienna, Austria; simon.schneider@nhm-wien.ac.at - Martin Zuschin, University of Vienna, Department of Palaeontology, Althanstrasse 14, 1090 Vienna, Austria

This article intends to summarise the current state of knowledge on the facies, biota, and age of the Ernstbrunn Limestone and Klentnice beds both at outcrop and from drill cores, and to provide a bibliography for these strata, similar to the compilation on the coeval Stramberk Limestone (Silesian Unit, NE Czech Republic) by Vašíček \& Skupien (2004, 2005). All Upper Jurassic klippen of the Waschberg-Ždánice Unit, stretching from Niederfellabrunn to Kleinschweinbarth in Lower Austria, and further on to the Pavlovské vrchy (Pavlov Hills) of the Mikulov area in Czech Republic are considered, and data on their tectonic formation are compiled. The summary is split into four parts, covering (1) the geological overview and tectonic evolution, (2) the stratigraphy of the klippen, (3) the sedimentology and microfacies of the Ernstbrunn Limestone and Klentnice beds, and (4) the fossil flora and fauna that have been preserved in these rocks. Furthermore, we outline the geological and palaeontological significance of the 


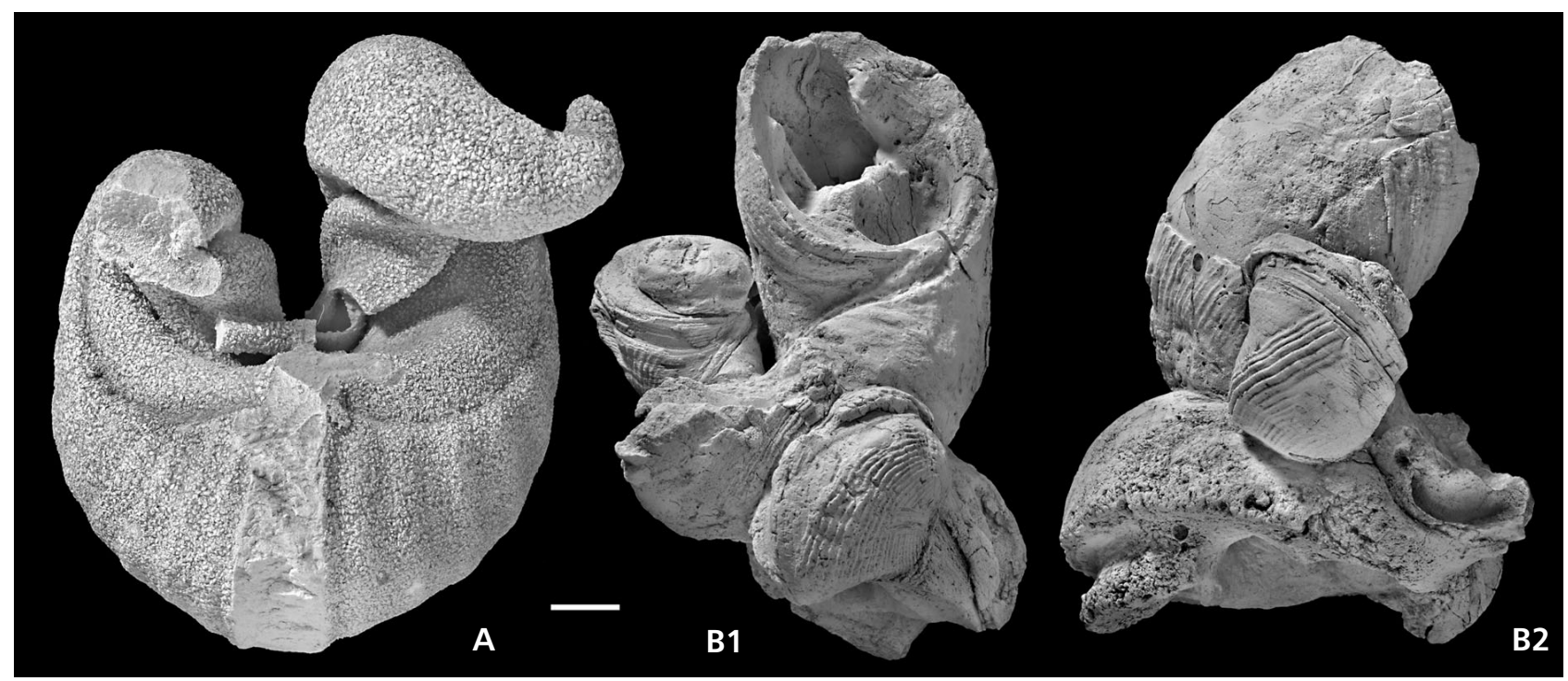

Figure 1. Epidiceratidae: Character fossils of the Ernstbrunn Limestone. • A - internal mould of Epidiceras sp.; Dörfles; NHMW 2012/0108/0002. - B - small cluster of five specimens of Heterodiceras lucii (Defrance, 1819) from a karst fissure at Dörfles V quarry; NHMW 2012/0111/0001. - B1 - small double-valved specimen (upper left), adult left valve (upper right), and two fragmentary specimens (left- and right-central) growing on a single right valve (below). $\bullet \mathrm{B} 2-$ same cluster as in B1; side view. Scale bar $=10 \mathrm{~mm}$.

Ernstbrunn Limestone and Klentnice beds, and highlight potential future directions of research.

Most people familiar with the Upper Jurassic Ernstbrunn Limestone likely will think of epidiceratid bivalves when this unit is mentioned - and with a bivalve it all began. When Karl Haidinger (1782) reported on an epidiceratid bivalve unearthed from the carbonates of the Semmelberg near Ernstbrunn, he considered this find a rarity. In fact, he had discovered the character fossil of the stratum, i.e. a large internal mould of a basal rudist (Fig. 1A). However, it took almost 50 more years, until geological investigations on the Ernstbrunn Limestone started. It was Ami Boué, who "painted" a first picture of these carbonates in his "Geognostisches Gemälde von Deutschland" (Boué 1829) and established the term "Calcaire d'Ernstbrunn" (= Ernstbrunn Limestone) in his follow-up article on the Mesozoic stratigraphy of the "Austrian Alps" (Boué 1830). Since then, many famous Austrian and Czech geologists have contributed to the discussion about the nature and origin of the enigmatic Upper Jurassic hill chain that occurs to the north of Vienna, between the Danube and Thaya rivers (see bibliography below). Finally, these rocks were recognised as unrooted tectonic klippen that have been sheared off the Mesozoic basement below the Vienna Basin, and dragged up in the course of the thrusting of the Waschberg-Ždanice Nappe onto the Alpine-Carpathian Foredeep (= Molasse Unit; Figs 2, 3) (Poul et al. 2011, Wessely 2006).

Besides the vivid discussion on structural geology, first essays on the lithology and fauna of several outcrops of Ernstbrunn Limestone were compiled by Ferstl (1845),
Prinzinger (1851), Hingenau (1852), Foetterle (1853), and Hobza (1876). In the late $19^{\text {th }}$ century, Abel $(1899 \mathrm{a}, \mathrm{b})$ provided a comprehensive description of the sediments and listed the fossil fauna of the Ernstbrunn Limestone. Scattered over the $20^{\text {th }}$ century, several classical, macroscopic facies descriptions of the stratum were published (e.g., Jüttner 1922, 1942; Schön 1927; Tollmann 1963), until the microfacies of the Ernstbrunn Limestone was studied in detail in Moravia (Eliáš 1992; Eliáš \& Eliášová 1984, 1986; Řehánek 1987a, b) and in Austria (Hofmann 1990a, Moshammer \& Schlagintweit 1999). The latter authors provide modern lithologic characterisations of the Ernstbrunn Limestone at Dörfles and a few other small outcrops (Fig. 4). Information on the microfacies of several major outcrops (e.g., Falkenstein, Staatz), however, is still wanting, and a comprehensive facies model for the Ernstbrunn-Pavlov Carbonate Platform has not been proposed.

After the first description by Haidinger (1782), the abundant, large fossils preserved in the Ernstbrunn Limestone soon had attracted both collectors and scientists (e.g., Hoernes 1874; Makowsky 1874; Peters 1855, 1867; Suess 1858). In the $20^{\text {th }}$ century, the fossil fauna of the Ernstbrunn Limestone was treated in several unpublished Ph.D. theses (Bachmayer 1940, Dürrmayer 1931, Matzka 1934, Moeller 1911). However, only a few peculiar species or genera were formally described, and several moderately specious taxa were monographed (see palaeontology section below). A milestone for further investigation was set, when the ammonite fauna and biostratigraphy of the Ernstbrunn Limestone were revised (Zeiss \& Bachmayer 1989, Zeiss 2001). Recently, a re-evaluation of the extraordinarily rich 

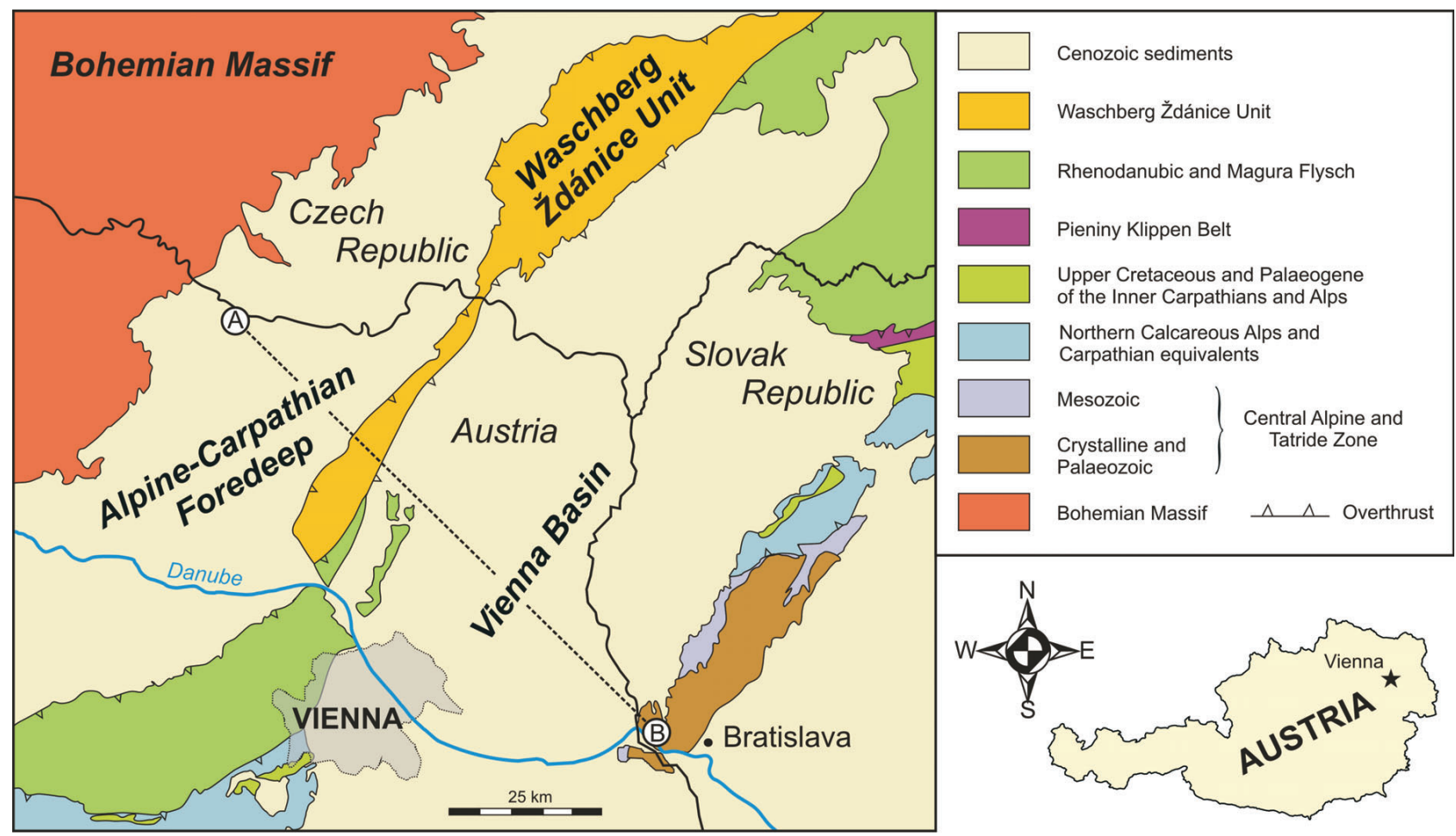

Figure 2. Main tectonic units of the study region, including the Waschberg-Ždánice-Unit (WZU). Dashed line (A-B) indicates position of cross-section in Fig. 3.

A Molasse Unit WZU

Vienna Basin

Carpathians B

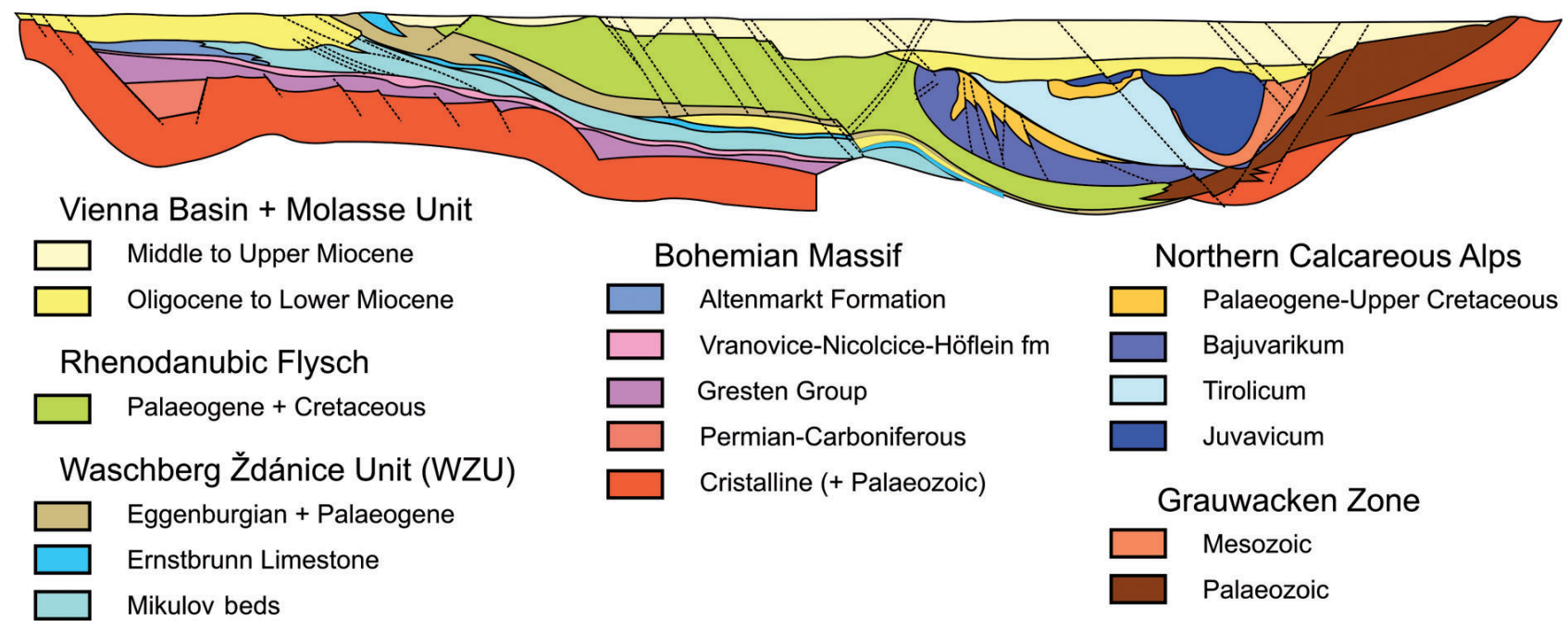

Figure 3. Schematic cross-section of the Molasse, Waschberg-Ždánice, and Flysch units and adjacent Vienna Basin. Modified from Zimmer \& Wessely (1996).

decapod fauna of the Ernstbrunn Limestone has been started, which already produced a wealth of results (Feldmann \& Schweitzer 2009; Robins et al. 2012, 2013; Schweitzer \& Feldmann 2008a, b, 2009a-d, 2010a-d). Major portions of the fauna, however, including several of the most specious groups (e.g., Scleractinia, Bivalvia, Gastropoda, Brachiopoda, Echinoidea), have never been studied in detail. As a result, knowledge on the palaeobiodiversity and palaeoecology of the Ernstbrunn-Pavlov Carbonate Platform remains piecemeal, despite of more than 200 years of research.

Any comprehensive essay on the Ernstbrunn Limestone will necessarily also expand on the closely associated Klentnice beds. Generally, the Klentnice beds comprise a 
Table 1. Locality names and GPS coordinates of current and former outcrops of Ernstbrunn Limestone (E) and Klentnice beds (K), inferred from labels of fossils in the collections of NHMW. Numbers in the first column correspond to Fig. 4. Localities without number and coordinates could not be matched with a particular outcrop.

\begin{tabular}{|c|c|c|}
\hline \multicolumn{2}{|c|}{ NR Stratum Locality } & \multirow{2}{*}{$\frac{\text { Coordinates }}{48^{\circ} 32^{\prime} 43.81^{\prime \prime} \mathrm{N} 16^{\circ} 21^{\prime} 00.52^{\prime \prime} \mathrm{E}}$} \\
\hline $1 \mathrm{E}$ & Dörfles I & \\
\hline $2 \mathrm{E}$ & Dörfles II & $48^{\circ} 32^{\prime} 45.94^{\prime \prime} \mathrm{N} 16^{\circ} 20^{\prime} 58.67^{\prime \prime} \mathrm{E}$ \\
\hline $3 \mathrm{E}$ & Dörfles III & $48^{\circ} 32^{\prime} 53.77^{\prime \prime} \mathrm{N} 16^{\circ} 20^{\prime} 50.86^{\prime \prime} \mathrm{E}$ \\
\hline $4 \mathrm{E}$ & Dörfles IV & $48^{\circ} 32^{\prime} 57.21^{\prime \prime} \mathrm{N} 16^{\circ} 20^{\prime} 53.47^{\prime \prime} \mathrm{E}$ \\
\hline $5 \mathrm{E}$ & Dörfles V & $48^{\circ} 33^{\prime} 03.53^{\prime \prime} \mathrm{N} 16^{\circ} 20^{\prime} 47.59^{\prime \prime} \mathrm{E}$ \\
\hline $6 \mathrm{E}$ & $\begin{array}{l}\text { Ernstbrunn Kalkwerk II, } \\
\text { Ernstbrunn II }\end{array}$ & $48^{\circ} 32^{\prime} 52.34^{\prime \prime} \mathrm{N} 16^{\circ} 21^{\prime} 21.08^{\prime \prime} \mathrm{E}$ \\
\hline $7 \mathrm{E}, \mathrm{K}$ & Ernstbrunn (Semmelberg) & $48^{\circ} 31^{\prime} 58.36^{\prime \prime} \mathrm{N} 16^{\circ} 20^{\prime} 54.76^{\prime \prime} \mathrm{E}$ \\
\hline$-\mathrm{E}$ & Kottingneusiedl & - \\
\hline$-\mathrm{E}$ & Grafensulz & - \\
\hline $8 \mathrm{E}$ & Michelstetten (Galgenberg) & $48^{\circ} 35^{\prime} 44.05^{\prime \prime} \mathrm{N} 16^{\circ} 26^{\prime} 38.05^{\prime \prime} \mathrm{E}$ \\
\hline $9 \mathrm{E}$ & Falkenstein (Steinbruch) & $48^{\circ} 43^{\prime} 38.86^{\prime \prime} \mathrm{N} 16^{\circ} 35^{\prime} 01.29^{\prime \prime} \mathrm{E}$ \\
\hline$-\mathrm{E}$ & Falkenstein (not specified) & - \\
\hline $10 \mathrm{E}$ & Klafterbrunn I & $48^{\circ} 33^{\prime} 36.43^{\prime \prime} \mathrm{N} 16^{\circ} 21^{\prime} 07.68^{\prime \prime} \mathrm{E}$ \\
\hline $11 \mathrm{E}$ & Klafterbrunn II & $48^{\circ} 33^{\prime} 33.74^{\prime \prime} \mathrm{N} 16^{\circ} 21^{\prime} 09.40^{\prime \prime} \mathrm{E}$ \\
\hline $12 \mathrm{E}$ & Klafterbrunn III & $48^{\circ} 33^{\prime} 29.36^{\prime \prime} \mathrm{N} 16^{\circ} 21^{\prime} 13.42^{\prime \prime} \mathrm{E}$ \\
\hline $13 \mathrm{E}$ & Klafterbrunn IV & $48^{\circ} 33^{\prime} 25.36^{\prime \prime} \mathrm{N} 16^{\circ} 21^{\prime} 14.61^{\prime \prime} \mathrm{E}$ \\
\hline $14 \mathrm{E}, \mathrm{K}$ & Klement I & $48^{\circ} 34^{\prime} 06.31^{\prime \prime} \mathrm{N} 16^{\circ} 21^{\prime} 02.43^{\prime \prime} \mathrm{E}$ \\
\hline $15 \mathrm{E}$ & Mikulov (Marienmühle) & $48^{\circ} 48^{\prime} 39.34^{\prime \prime} \mathrm{N} 16^{\circ} 39^{\prime} 31.21^{\prime \prime} \mathrm{E}$ \\
\hline$-\mathrm{E}$ & Asparn an der Zaya & - \\
\hline $16 \mathrm{E}, \mathrm{K}$ & Leiser Berg bei Niederleis & $48^{\circ} 33^{\prime} 33.25^{\prime \prime} \mathrm{N} 16^{\circ} 22^{\prime} 25.77^{\prime \prime} \mathrm{E}$ \\
\hline $17 \mathrm{E}$ & Staatz & $48^{\circ} 40^{\prime} 34.71^{\prime \prime} \mathrm{N} 16^{\circ} 29^{\prime} 17.14^{\prime \prime} \mathrm{E}$ \\
\hline $18 \mathrm{~K}-\mathrm{E}$ & Südmährerkreuz & $48^{\circ} 45^{\prime} 43.75^{\prime \prime} \mathrm{N} 16^{\circ} 36^{\prime} 48.35^{\prime \prime} \mathrm{E}$ \\
\hline $19 \mathrm{~K}-\mathrm{E}$ & Steinbruch bei Schletz & $48^{\circ} 34^{\prime} 49.78^{\prime \prime} \mathrm{N} 16^{\circ} 27^{\prime} 10.81^{\prime \prime} \mathrm{E}$ \\
\hline $20 \mathrm{~K}$ & Niederfellabrunn & $48^{\circ} 28^{\prime} 04.64^{\prime \prime} \mathrm{N} 16^{\circ} 18^{\prime} 14.19^{\prime \prime} \mathrm{E}$ \\
\hline $21 \mathrm{~K}$ & Buschberg NE Klement & $48^{\circ} 34^{\prime} 37.42^{\prime \prime} \mathrm{N} 16^{\circ} 23^{\prime} 44.84^{\prime \prime} \mathrm{E}$ \\
\hline $22 \mathrm{~K}$ & Stützenhofen & $48^{\circ} 44^{\prime} 30.60^{\prime \prime} \mathrm{N} 16^{\circ} 36^{\prime} 30.90^{\prime \prime} \mathrm{E}$ \\
\hline $23 \mathrm{~K}$ & Niederfellabrunn (Hundsberg) & $48^{\circ} 28^{\prime} 37.40^{\prime \prime} \mathrm{N} 16^{\circ} 18^{\prime} 28.70^{\prime \prime} \mathrm{E}$ \\
\hline $24 \mathrm{~K}$ & Mikulov (Gemeindeberg) & $48^{\circ} 48^{\prime} 36.73^{\prime \prime} \mathrm{N} 16^{\circ} 38^{\prime} 15.59^{\prime \prime} \mathrm{E}$ \\
\hline $25 \mathrm{~K}$ & Mikulov (Heiliger Berg) & $48^{\circ} 48^{\prime} 27.11^{\prime \prime} \mathrm{N} 16^{\circ} 38^{\prime} 55.39^{\prime \prime} \mathrm{E}$ \\
\hline $26 \mathrm{~K}$ & Děvín (Maydenberg) & $48^{\circ} 52^{\prime} 09.94^{\prime \prime} \mathrm{N} 16^{\circ} 38^{\prime} 07.94^{\prime \prime} \mathrm{E}$ \\
\hline$-\mathrm{E}$ & $\begin{array}{l}\text { Perná N Nikolsburg } \\
\text { [Makowsky 1874] }\end{array}$ & - \\
\hline $27 \mathrm{~K}$ & Niederfellabrunn & $48^{\circ} 27^{\prime} 45.11^{\prime \prime} \mathrm{N} 16^{\circ} 18^{\prime} 12.13^{\prime \prime} \mathrm{E}$ \\
\hline $28 \mathrm{E}$ & Mikulov (Quarry Holy Mt.) & $48^{\circ} 48^{\prime} 31.06^{\prime \prime} \mathrm{N} 16^{\circ} 39^{\prime} 16.44^{\prime \prime} \mathrm{E}$ \\
\hline $29 \mathrm{E}, \mathrm{K}$ & Mikulov (Turold Quarry) & $48^{\circ} 49^{\prime} 00.51^{\prime \prime} \mathrm{N} 16^{\circ} 38^{\prime} 23.91^{\prime \prime} \mathrm{E}$ \\
\hline $30 \mathrm{~K}$ & Klentnice (Table Mountain) & $48^{\circ} 50^{\prime} 56.38^{\prime \prime} \mathrm{N} 16^{\circ} 38^{\prime} 11.98^{\prime \prime} \mathrm{E}$ \\
\hline
\end{tabular}

mixture of fossiliferous siliciclastics and carbonates (see sedimentology section below) and grade vertically and laterally into the pure carbonates of the Ernstbrunn Limestone (Glaessner 1931, Jüttner 1922; cf. Poul et al. 2011). The term "Klentnitzer Mergel” (= Klentnitz Marls) was introduced by Abel (1899a), who was among the first scientists to provide a detailed description of this stratum, including a list and several drawings of the fauna (Abel 1897). The name refers to the informal type locality, Klentnice (Klentnitz), located to the north of Mikulov (Czech Republic).

Since the 1950s, the sediments of the Molasse and Waschberg units in Austria and Czech Republic have been penetrated by numerous wells reaching down to the crystalline basement of the Bohemian Massif. In several drill cores, the autochthonous Mesozoic succession on the crystalline slope contains both Ernstbrunn Limestone and Klentnice beds, which finally proved the tectonic scenario outlined above (e.g., Adámek 1979, 1986; Eliáš \& Wessely 1990; Malzer et al. 1993; Poul et al. 2011; Wessely 2006). Recently, new data retrieved from subsurface rocks and surface geology have been integrated, producing a more complete view of the klippen strata (Adámek 2005, Poul et al. 2011, Wessely 2006). Since the 1970s, an additional set of lithostratigraphic units and terms has been developed for the autochthonous Mesozoic strata in subsurface (see Eliáš \& Wessely 1990 for an overview).

Abbreviations used in the text. $-\mathrm{GBA}=$ Geologische Bundesanstalt, Vienna; NHMW = Natural History Museum Vienna; WZU = Waschberg-Ždánice Unit.

\section{State of the art}

\section{Geographic overview, geology and tectonics}

At surface, the Ernstbrunn Limestone and Klentnice beds occur within a SW-NE trending hill chain that starts at the Waschberg north of Stockerau (Lower Austria) and ends at the Děvín (Maydenberg) west of Pavlov (Pollau) in southern Moravia (Czech Republic), thus extending between the Danube and Thaya rivers over approximately $60 \mathrm{~km}$ (Fig. 2), and probably even a few kilometres further to the north (Pícha \& Hanzlíková 1965). Together with the elongated strip of surrounding sediments these hills form a distinct tectonic unit, named Waschberg Zone according to the concepts developed by Tercier (1936) and Grill (1953) [note that at that time the strict restriction of the term "Zone" to the biostratigraphic nomenclature was not established]. Czech geologists have designed an alternative term, i.e. Ždánice "Zone" (also Ždánice-Subsilesian "Zone"), for the same unit (Roth 1962). Since there is no official agreement on a common name, a combination of both names is used herein. With regard to structural geology, the Waschberg-Ždánice Unit (WZU) represents the most distal Alpine-Carpathian nappe in the boundary region between these two orogens. Moreover, the WZU is the only structural element that forms a direct connection of the Alps and Carpathians at surface (Prey 1960, 1965; Roth 
1967; Tollmann 1971; Fig. 2). Towards the north, the WZU is bordered by the Alpine-Carpathian Foredeep, which has been partly overthrust by the WZU during the Late Styrian tectonic phase at the Karpatian/Badenian (= Early/Middle Miocene) boundary (Pokorný 1973, Tollmann 1966; Figs 2, 3). In its easternmost part, the Pouzdřany thrust sheet is inserted between the Alpine-Carpathian Foredeep and the WZU. In turn, the WZU is overthrust by the Rhenodanubian Flysch, as can be seen in the south-western part of the WZU. Because of its sandwiched tectonic position between the Molasse and Flysch zones (Fig. 3), the WZU has been thought to represent an eastern prolongation of the Helvetic Unit by several scholars (Tercier 1936, Tollmann 1963, Trauth 1948). In its .

西 
southern part, the Austrian WZU is tectonically partitioned into two subunits, i.e. the outer Roselsdorf Unit and the inner Waschberg Unit sensu stricto. Further partitioning into several blocks occurred along reactivated faults of Variscan strike (Poul et al. 2011, Wessely 2006).

The regular sedimentary succession of the WZU consists of Miocene strata. Several of the hills, which are composed of Oligocene, Eocene, Palaeocene, Upper Cretaceous, and Upper Jurassic rocks (Fig. 4), rear up as more or less steep blocks, and thus are termed "cliffs" in common speech. The Upper Jurassic strata form major parts of the Leis Hills complex (Leiser Berge), including Semmelberg, Dörfles (Fig. 5A, B), Klement, and Buschberg localities, and the hills of Staatz (Wessely \& Hofmann 2007; Fig. 5D), Falkenstein (Fig. 5C), Stützenhofen (Fig. 5F), and Kleinschweinbarth in Lower Austria. In the Czech Republic, in and around Mikulov (Nikolsburg) in southern Moravia, they comprise (Fig. 4) the Pavlov Hills (Pavlovské vrchy, Pollauer Berge), i.e. the Saint Hill (Svatý kopeček, Heiligenberg), Turold, Table Mountain (Stolová hora, Tafelberg), and Děvín (Maydenberg; Fig. 5E). Stratigraphically, both the Klentnice beds and the Ernstbrunn Limestone have not yet been formalised and type localities and sections have not been officially designated or described. Consequently, both units are not termed formations herein. Moreover, we favour the term "Klentnice beds" versus "Klentnice Marls", since the stratum comprises a variety of different facies (see sedimentology section below). Recently, Poul et al. (2011) proposed a separate informal unit termed "nodular limestones" for a transitional zone between the Klentnice beds and Ernstbrunn Limestone in the Pavlov Hills. The term "nodular limestone" is commonly attributed to condensed limestone facies deposited around the calcite compensation depth (Jenkyns 1974). This does not account for the facies found in the Pavlov Hills. Moreover, any approach to separate different units along a gradual transition will remain arbitrary. Herein, we thus assign all well-bedded portions of Upper Jurassic rocks in the WZU to the Klentnice beds.

During the last 40 years, a series of lithostratigraphic units and terms have been established in order to characterise the subsurface, autochthonous Mesozoic strata on the southern slope of the Bohemian Massif (e.g., Eliás 1974, Ladwein 1976), which have been summarized and harmonized by Eliáš \& Wessely (1990). According to the resulting scheme, the Upper Jurassic portion of the succession starts with the Vranovice limestones and dolomites, which have no equivalent at surface. These carbonates are overlain by the Mikulov Marls and the Kurdějov Arenite. The latter two units are considered equivalents of the Klentnice beds. Due to the lack of information on the typical succession of the Klentnice beds, however, it remains enigmatic whether these strata are effectively facially equivalent. The Jurassic succession is topped by the Ernstbrunn Limestone, which is capped by erosion, and overlain by limestones of Late Cretaceous age (Adámek 1979, 1986; Eliáš \& Wessely 1990; Pokorný 1958; Poul et al. 2011).

The initial, most controversial and still enduring discussion concerns the origin of the Jurassic rocks of the WZU, and several contrasting theories were proposed on that subject. The "island theory" - most popular during the early years of research - identified the Jurassic klippen as erosional relics of a formerly continuous cover of Jurassic rocks on the crystalline basement, which acted as islands in the Cenozoic Paratethys Sea (e.g., Stejskal 1932, Suess 1929, Uhlig 1904). In this context, the Ernstbrunn Limestone has also been thought to represent a prolongation of the Upper Jurassic strata of the Ortenburg-Passau region (Lower Bavaria, SE Germany; Suess 1885), which, however, are true erosional relics of different facies and age resting directly on the crystalline slope (Gröschke 1985). Other scholars regarded the klippen as large olistolithes that were derived from a now eroded Jurassic shelf in superior position (e.g., Stejskal 1928, 1930, 1931, 1935b; Uhlig 1903). When a first set of boreholes penetrated several unrooted Carpathian klippen in the Silesian flysch unit in the early $20^{\text {th }}$ century, scientists began to discuss a similar tectonic model for the Ernstbrunn Limestone (Friedl 1927; Jüttner 1930, 1931, 1932, 1933b, 1934; Petrascheck 1914, 1921; Schnabel 1929, 1933a, b). Starting from 1948, numerous wells also penetrated the sedimentary successions of the AlpineCarpathian Foredeep and WZU both in Austria and Czech Republic, mainly in order to explore the hydrocarbon resources of the region (Eliáš \& Wessely 1990, Tollmann 1985). The new data confirmed the presence of Upper Jurassic strata identical to the Ernstbrunn Limestone and Klentnice beds in the autochthonous Mesozoic cover of the slope of the Bohemian Massif (Brix \& Götzinger 1964; Brix et al. 1977; Eliáš 1977, 1981; Eliáš \& Wessely 1990; Grill 1958; Kapounek et al. 1967; Kröll 1980; Malzer et al. 1993; Wessely 1993, 1997, 2006; Zimmer \& Wessely 1996). It is therefore confirmed that the Upper Jurassic blocks originate from below the WZU and thus truly represent un-rooted tectonic klippen, but not olistolithes (Kapounek et al. 1967, Poul et al. 2011, Wessely 2006). Based on detailed geologic mapping, borehole data, and seismic analysis that were in part already presented by Stráník et al. (1979), Poul et al. (2011) recently developed a comprehensive model of the tectonic evolution of the Pavlov Hills expanding on details of the partitioning of the Jurassic rocks due to thrusting and strike-slip movements. The resulting scheme shows that the Pavlov klippen extend much further in subsurface than those in the southern part of the WZU, with only relatively small horst structures cropping out. 

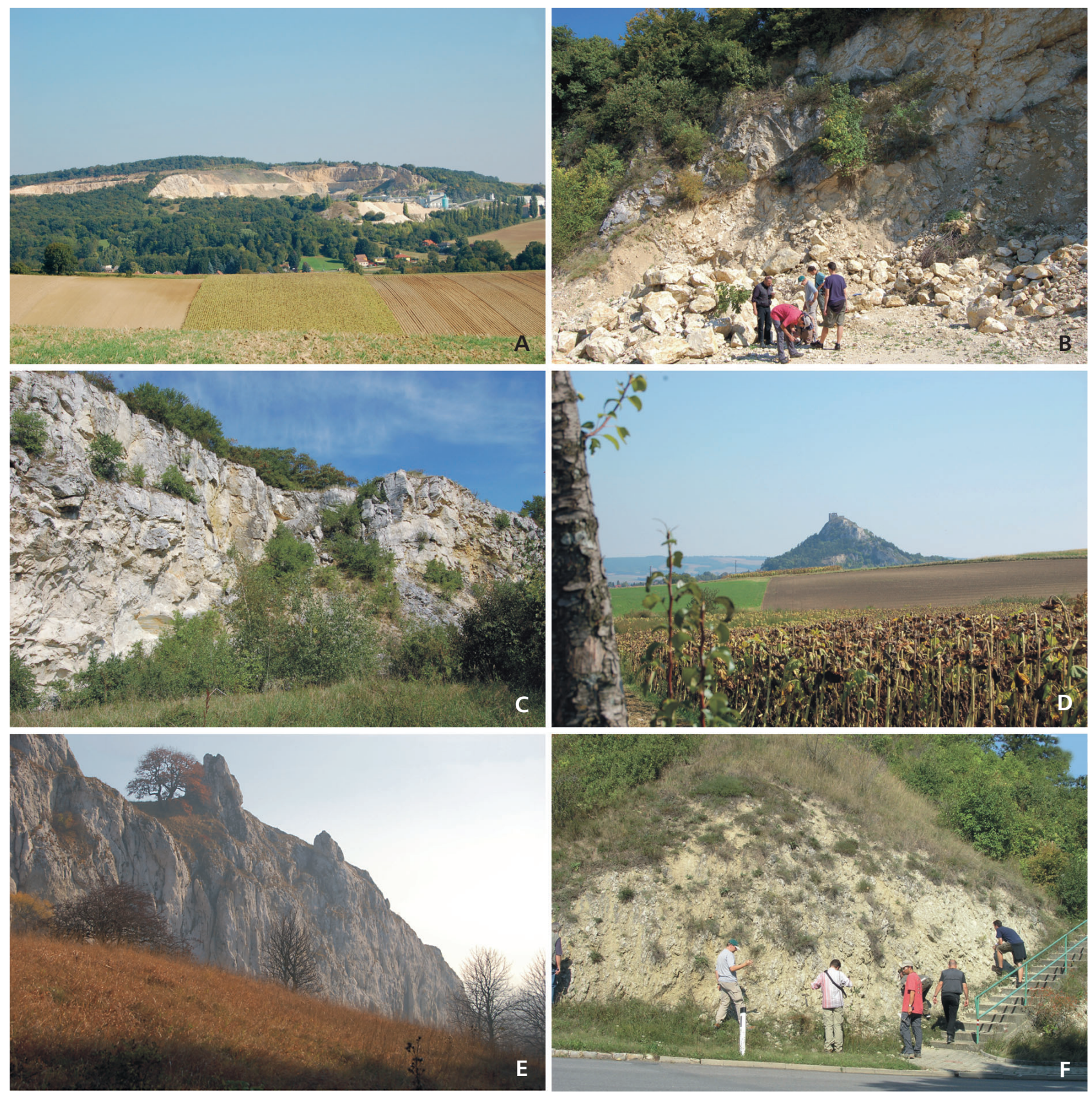

Figure 5. Major outcrops of Ernstbrunn Limestone (A-E) and Klentnice beds (F). $\bullet A-$ Ernstbrunn Kalkwerk II quarry. • B - Dörfles V quarry. $\bullet$ C - Falkenstein quarry. $\bullet$ D - Staatz Klippe. $・$ E - Děvín north of Mikulov. $\bullet$ F - roadcut at Stützenhofen.

\section{Stratigraphy}

Biostratigraphy of the Upper Jurassic klippen strata is still not settled and alternative stratigraphic approaches, e.g., sequence stratigraphy, isotope geochemistry, or palaeomagnetics, have never been tested for the Jurassic rocks of the WZU. The first author who clearly stated a Jurassic age for the Klentnice beds was Suess (1852). A few years later, Zittel (1868), based on the macrofauna of the Klentnice beds, regarded the Jurassic klippen as older than Tithonian.
Typically, Jurassic biostratigraphy is based on ammonites. They are, however, relatively rare in most outcrops of the Ernstbrunn Limestone and Klentnice beds and therefore ammonite biostratigraphy on the klippen strata started relatively late.

Most ammonites from the Klentnice beds have been unearthed from wine cellars at Niederfellabrunn. These relatively poorly preserved specimens and a few other finds have been extensively discussed, and determinations of earlier publications were usually emended by 
subsequent authors (Abel 1897, Arkell 1956, Bachmayer 1957, Krafft 1897, Kutek \& Zeiss 1988, Spath 1933, Vašíček 1971, Vetters 1905, Zeiss 1977). According to the latest update by Kutek \& Zeiss (1988) and Zeiss (2001), the seven ammonite taxa known from the Klentnice beds largely suggest an early Late Tithonian age (Micracanthoceras microcanthum Zone, Simplisphinctes Subzone; Ogg et al. 2008).

Besides ammonites, different microfossils were locally employed for biostratigraphy. From a single locality in the Pavlov Hills a rich fauna of Foraminifera and Ostracoda from the lower part of the Klentnice beds was studied (Hanzlíková 1962, 1965; Pokorný 1973), which produced conflicting results. While a latest Oxfordian to Late Kimmeridgian age was deduced from the Foraminifera (Hanzlíková 1965), a Late Tithonian to Berriasian age was inferred from the Ostracoda (Pokorný 1973). A re-evaluation, however, confirmed a Kimmeridgian age for both groups (Gramann \& Luppold 1991, Schudack \& Schudack 1997).

Relatively sound biostratigraphic data are also available for the autochthonous Mesozoic in subsurface. Ammonites from several wells in southern Moravia described by Vašíček $(1971,1980)$ indicate a ?Callovian to Oxfordian age for the Vranovice limestones and dolomites, while Brix et al. (1977) report an Oxfordian to latest Kimmeridgian age for the same stratum in Austria. The overlying Mikulov Marls, corresponding to the lower portion of the Klentnice beds have been dated as Kimmeridgian to early Middle Tithonian (Holzknecht \& Hamršmíd 1988; Vašíček 1980) or Early Tithonian (Brix et al. 1977). The Kurdějov Arenite, representing the upper portion of the Klentnice beds at subsurface, is interpreted to comprise upper Middle to lower Upper Tithonian deposits ( $c f$. Brix et al. 1977, Vašíček 1980). Papp \& Turnovsky (1964) studied the microfauna from drill cores from the Austrian part of the WZU and concluded on a Late Jurassic (?Tithonian) to Berriasian (?Hauterivian) age for the equivalents of the Klentnice beds. Brix et al. (1977) regard the microfauna derived from these cores as stratigraphically largely indistinct, but propose an exclusively Late Jurassic age for the Klentnice beds.

In contrast to the specimens from the Klentnice beds, the ammonites from the Ernstbrunn Limestone are usually well preserved. Up to the 1950s, only few specimens were available for study (Abel 1899a, b; Arkell 1956; Bachmayer 1957; Moeller 1911; Spath 1933). The most comprehensive assessment of the ammonites by Zeiss is mainly based on the extensive collections of Friedrich Bachmayer (Zeiss 1999, 2001; Zeiss \& Bachmayer 1989). In conclusion, Zeiss (2001) proposes middle Middle to early Late Tithonian age (Richterella richteri Zone to Micracanthoceras microcanthum Zone, Simplisphinctes Subzone) for the Ernstbrunn Limestone. It should be mentioned that the majority of the ammonite specimens were collected at Ernstbrunn-Dörfles Werk II quarry, while most of the other fossils, usually representing benthic taxa were found at other quarries. This suggests significant variation in facies between the different klippen and outcrops - and probably also differences in age.

An alternative biostratigraphic approach based on calpionellids is restricted to several exposures of Ernstbrunn Limestone in the Mikulov region, and revealed a much younger, Tithonian to Hauterivian age (Eliáš \& Eliášova 1985, Houša \& Řehánek 1987, Houša et al. 1963). Likewise, a study of microflora and microfauna from several small outcrops of Ernstbrunn Limestone (Kleinschweinbarth, surroundings of Ernstbrunn, Galgenberg, surroundings of Falkenstein and Schletz) points to a Tithonian to Early/Middle Berriasian age (Moshammer \& Schlagintweit 1999).

In conclusion, the Klentnice beds are thought to comprise the Kimmeridgian to early Late Tithonian, while the Ernstbrunn Limestone may have been deposited during the Middle Tithonian to Berriasian (?Hauterivian). According to this scenario, the Ernstbrunn-Pavlov Carbonate Platform persisted during the Jurassic-Cretaceous transition and is thus entirely coeval to the Stramberk Limestone of northern Moravia.

\section{Sedimentology and facies}

The sedimentology and microfacies of the Pavlov Hills have been explored in detail (Eliáš 1962; Eliáš \& Eliášová 1984, 1986; Fabian \& Jüttner 1937; Jüttner 1933a; Matějka 1926, 1929; Matějka \& Stráník 1961; Řehánek 1987a, b), but published data from the Ernstbrunn Limestone and Klentnice beds in Austria are sparse. Comprehensive general sedimentological characterisation of several outcrops in Austria has been provided by Glaessner (1937). The texture and faulting of the Ernstbrunn Limestone are accurately described by Schön (1927) and Havír \& Stráník (2003). At several outcrops, for example at Staatz or the southern flank of the Děvín, large, severely brecciated rock portions provide evidence of the tectonic movements outlined above (Petrascheck 1921, Zapletal 1930).

In the 1980s, modern microfacies analysis of the Ernstbrunn Limestone of the Pavlov Hills started, and numerous carbonate thin sections were screened by Eliáš \& Eliášová (1984, 1986) and Řehánek (1987a, b). In Austria, the microfacies of the five classical, now abandoned quarries at Dörfles was analysed in a diploma thesis by Hofmann (1990a). He provided schematic sections and identified different types of lagoonal microfacies, i.e. wackestones, packstones, grainstones, algal bindstones, and "diceratid" facies. However, only a brief overview of his results is published in Hofmann (1992b, 1993a, 2001). 
Several small outcrops of Ernstbrunn Limestone in Austria have been more or less randomly sampled by Moshammer \& Schlagintweit (2003), who recorded different types of inner and outer platform carbonates. The microfacies of most of the important outcrops of Ernstbrunn Limestone (e.g., Falkenstein, Michelstetten, Klement, Staatz, Stützenhofen), however, was never studied. Consequently, an integrative facies model for the Ernstbrunn-Pavlov Carbonate Platform is still lacking, as is a detailed comparison and correlation of autochthonous, subsurface rocks with those sediments available at outcrop.

According to the publications listed above, the Klentnice beds consist of claystones and marls, which dominate the lower portion of the stratum, while intercalations of limestone (ooid-, intraclast-, and bioclast-wacke- to packstones; Fig. 6B, D, H) become gradually more abundant towards the top. These facies are interpreted as base-of-slope to pelagic mud facies by Eliáš \& Eliášová (1984). However, because the shallow-water carbonates of the Ernstbrunn Limestone gradually developed from the Klentnice beds, the latter may rather represent shelf sediments deposited at moderate depth. This is underlined by the composition of the rich macrofauna (see below).

Similar to the Klentnice beds, the individual outcrops of Ernstbrunn Limestone are composed of several different types of facies (Fig. 6A, C, G). Fossiliferous or oncoidal wackestones and packstones, algal bindstones, and epidiceratid- and coral-framestones may represent different microhabitats of lagoonal settings, i.e. epidiceratid and coral patch reefs, and the carbonate sands and mud in between. Ooid-oncoid grainstones and packstones of variable grain size and degree of sorting may have been deposited in the form of fringing ooid-oncoid bars along the margins of the carbonate platform. Altogether, these sediments, preserved in numerous isolated klippen, provide a fairly complete view of the complex facies architecture of the Ernstbrunn-Pavlov Carbonate Platform.

In addition to the Jurassic rocks, the discordantly overlying Cretaceous strata and their relation to the Ernstbrunn Limestone were studied (Glaessner 1930). Moreover, several fissure fillings inserted in the carbonates at Staatz and Dörfles were analysed, and found to contain mixed assemblages of Tithonian, Late Cretaceous (Upper Campanian to Santonian), Palaeogene and Neogene micro- and nanofossils (Bachmayer 1964a, Hofmann et al. 1999).

Closely related to the sedimentology of the rocks, the present-day surface morphology and carstification of the Jurassic klippen, including several small caves, have been subjects of an unpublished Ph.D. thesis (Riedl 1958a) and several publications (Riedl 1957, 1958b, 1960). The geography and underlying geologic structures of the Pavlov Hills were detailed by Mikula (1927).

During the Middle Ages the Ernstbrunn Limestone has been used as a building stone, e.g., in the castles of Staatz and Falkenstein and the church of Michelstetten (Rohatsch $\&$ Thinschmidt 1997). Since more than 100 years, the limestone is intensively mined at Ernstbrunn-Dörfles, and is used as a natural resource for various construction materials and technical products (Bullinger 1997, Ernstbrunner Kalktechnik 2011). For the first time, Moshammer \& Lobitzer (1997) have published data on the chemical composition of the Ernstbrunn Limestone along with its colorimetric properties, and thus provided important information on the technical applicability of the rocks.

\section{Palaeontology}

The first fossil described from the Upper Jurassic rocks of the Waschberg Unit is a "Gienmuschel" [old German trivial name for Chama; Adelung 1793-1801], i.e. a fossil bivalve of the genus Epidiceras (Haidinger 1782; Fig. 1A), which is a character fossil of the Ernstbrunn Limestone. Usually, these bivalves occur together with Heterodiceras (Fig. 1B) as major components of the epidiceratid-nerineid biofacies, and are preserved as internal moulds of doublevalved specimens (Schneider 2012). According to Bachmayer (1957), the fossil fauna of the Ernstbrunn Limestone comprises more than 500 species, which is rather an underestimation according to our opinion (Fig. 7). Although several major taxonomic groups have not yet been studied in detail, more than 300 taxa have been identified and published.

As already outlined by Bachmayer (1940), the total abundance of fossils and composition of the fauna vary strongly among the different klippen and outcrops, which can easily be demonstrated by the following examples. (1) Corals are less diverse but much more abundant at Klafterbrunn 3 quarry than at any other locality. (2) In contrast, epidiceratids and nerineids typically occur in abundance in all quarries at Dörfles (Fig. 1A, B) as well as at Falkenstein and Mikulov Marienmühle (Mariánský mlýn) quarry, but have not been recorded from Klafterbrunn, Staatz, Turold, or Děvín. (3) Pharyngeal teeth of Lepidotes are very common at Falkenstein (Fig. 8F), but rare at most other localities. (4) Decapods are particularly abundant at Dörfles I and Klement I quarries (Bachmayer 1940) (Fig. 8B). (5) A major portion of the ammonites described by Zeiss (2001) have been collected from Dörfles Werk II quarry (see list below; Fig. 8D); a single specimen (described as Ernstbrunnia) comes from Galgenberg near Michelstetten (Lower Austria).

In particular, the Dörfles quarries are famous for their numerous large bivalves (Fig. 8C) and gastropods (Fig. 8I) preserved as internal moulds. Careful investigation of the limestone from Dörfles, however, predominantly reveals molluscs preserved with shell. Due to complete lithification of the carbonate sediment, the shells cannot be 
extracted and are thus usually not collected. Taking all these observations into account, the different klippen and outcrops of Ernstbrunn Limestone may represent different habitats and facies, which may have experienced different diagenetic histories (Schneider et al. 2011). Moreover, the individual klippen may deviate in age. Up to now, these differences have neither been systematically assessed nor discussed in the literature.

\section{Flora and fauna described from the Ernstbrunn Limestone and Klentnice beds}

In the following overview only those publications which employ scientific names at genus or species level are included.

Trace fossils. - Moshammer \& Schlagintweit (1999) recorded a single microcoprolite taxon from thin sections of Ernstbrunn Limestone. Several types of borings in shells or coral skeletons can be identified, which have been caused by Lithophaga, gastrochaenid bivalves, clionid sponges, and yet unidentified microborers (personal observation SS).

Nanofossils. - Stradner (1961) recorded "Coccolithus cf. pelagicus (Wallisch)" from unspecified "Tithonian strata" from a well. However, since Coccolithus pelagicus (Wallich, 1877) Schiller, 1930 is an entirely Cenozoic taxon (Bukry 1973), this is surely an artefact. Nine species of calcareous nanofossils were recorded by Holzknecht \& Hamršmíd (1988) from the Mikulov Marls derived from a borehole near Mikulov.

Microflora. - To date, no macrofloral remains have been discovered from the Ernstbrunn Limestone and Klentnice beds. However, major portions of the Ernstbrunn Limestone are characterised by abundant calcareous algae. Bachmayer (1944) described two new species of Dasycladales. Another two species of calcareous algae, again one of them new to science, are detailed by Kamptner (1951). Subsequently, Grill (1963) and Eliáš \& Eliášová (1986) listed calcareous algae from the Ernstbrunn Limestone. Thirty-three different taxa of algae, some of them of enigmatic affinities, have been identified from the Dörfles quarries by Hofmann (1990a, b, 1991a, b, 1992a, b, 1993b). Most of these taxa also belong to the Dasycladales and one of them is regarded as a new species by Hofmann (1994; emended by Schlagintweit 2011). Moshammer \& Schlagintweit (1999) also report five dasyclad species that were collected from several smaller outcrops of Ernstbrunn Limestone.

Foraminifera. - Similar to the algal flora, the microfauna of the Ernstbrunn Limestone can only be assessed by studying thin sections of the rocks. Grill (1963) was the first who studied Foraminifera from the Ernstbrunn Limestone and he reported several taxa in open nomenclature from Dörfles. Řehánek (1987a) listed six foraminifer taxa from the Pavlov Hills, Hofmann (1990a) identified seven taxa from Dörfles, and Moshammer \& Schlagintweit (1999) recorded five taxa from a few other localities. Noth (1951) mentions a foraminifer sample from the Upper Jurassic of Niederleis, but does not provide additional information. A list of Foraminifera from the Klentnice beds in Austria has been provided by Grill (1953), while the Foraminifera of an outcrop in Moravia have been monographed by Hanzlíkova (1965). Moreover, Papp \& Turnovsky (1964) and Holzknecht \& Hamršmíd (1988) provided data on microfauna from drill cores taken from autochthonous Mesozoic strata (Mikulov Marls).

Tintinnida. - Eliáš \& Eliášová (1985) and Řehánek (1987a) list more than 30 species of calpionellids from the Ernstbrunn Limestone from the Pavlov Hills.

Porifera. - The "chaetetid" fauna of the Ernstbrunn Limestone comprises four species of these coralline sponges (Bachmayer \& Flügel 1961b; Fig. 6F). However, during the following decades, many additional specimens have been collected by Bachmayer and are stored in the collections of NHMW. At several outcrops of the Klentnice beds a rich fauna of silicified calcareous sponges occurs (personal observation AK, SS; Fig. 9B, I, J), which is unstudied.

Hydrozoa. - Four species of Hydrozoa from the Ernstbrunn Limestone, including a new species, were described by Bachmayer \& Flügel (1961a). Similar to the "chaetetids", there is rich additional, unstudied material in the collections of NHMW.

Figure 6. Typical (micro-) facies of Ernstbrunn Limestone and Klentnice beds. • A - ooid-onkoid grainstone; Ernstbrunn Limestone; southern end of Děvín; NHMW 2012/0106/0003. • B - bioclast-ooid packstone; upper part of Klentnice beds; eastern flank of Děvín; NHMW 2012/0106/0001. -C - onkoid-grainstone; Ernstbrunn Limestone; Falkenstein quarry; NHMW 2011/0309/0001. • D - macro-ooid packstone; upper part of Klentnice beds; eastern flank of Děvín; NHMW 2012/0106/0004. • E - calcareous sponge (Barroisia sp.); longitudinal section; Dörfles; NHMW 2012/0108/0006. - F - coralline sponge (Chaetetopsis krimholzi Javorskij, 1947; det. F. Bachmayer); vertical section, with boring lithophagid bivalve in situ; Ernstbrunn Limestone; Dörfles I; NHMW 2012/0110/0002. • G - bioclast wackestone; Ernstbrunn Limestone; Dörfles I; NHMW 2012/0110/0001. • H - marlstone with ooids, peloids and sponge spicules; upper part of Klentnice beds; western flank of Děvín; NHMW 2012/0106/0002. Scale bars $=2 \mathrm{~mm}$. 


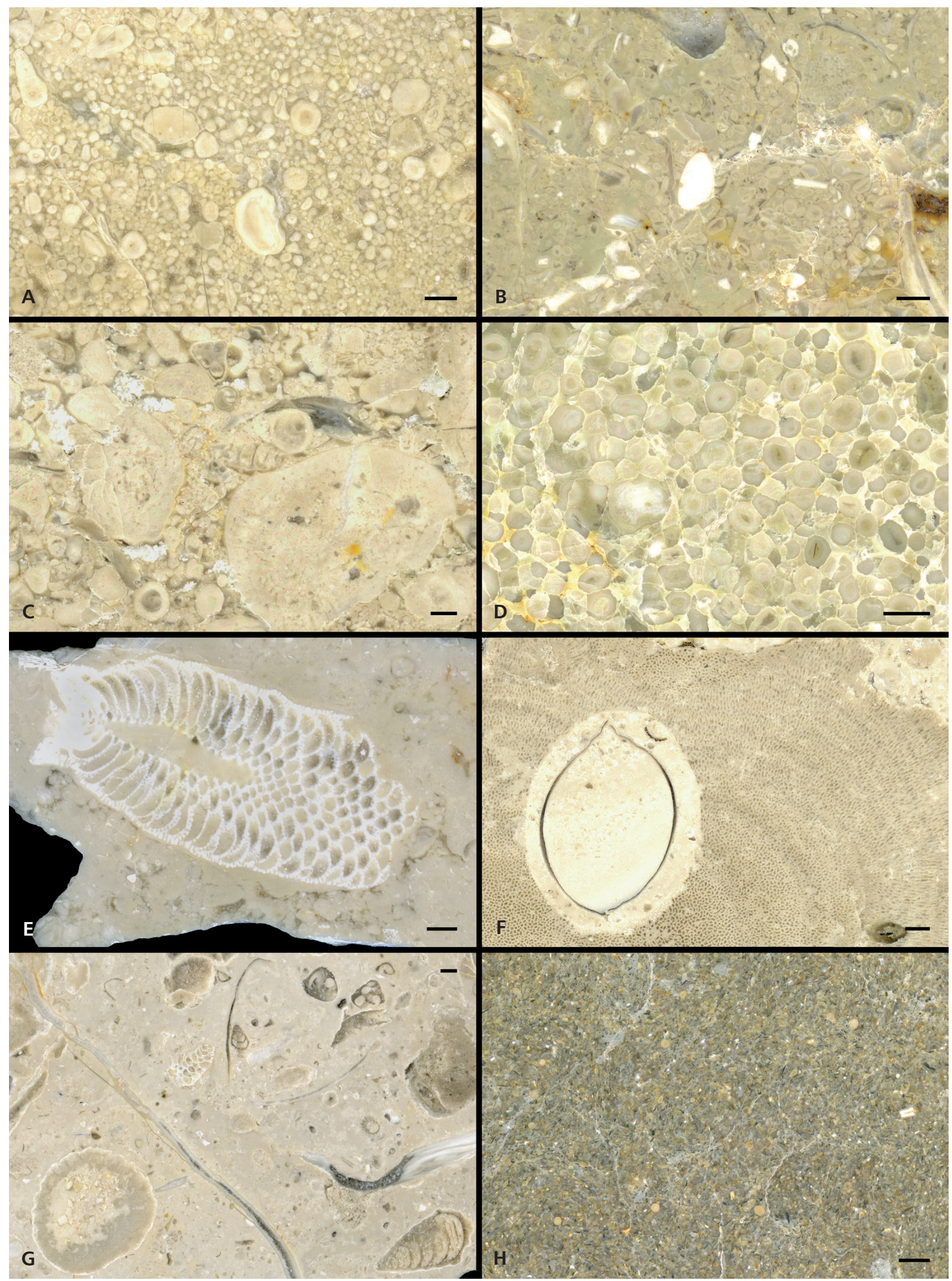




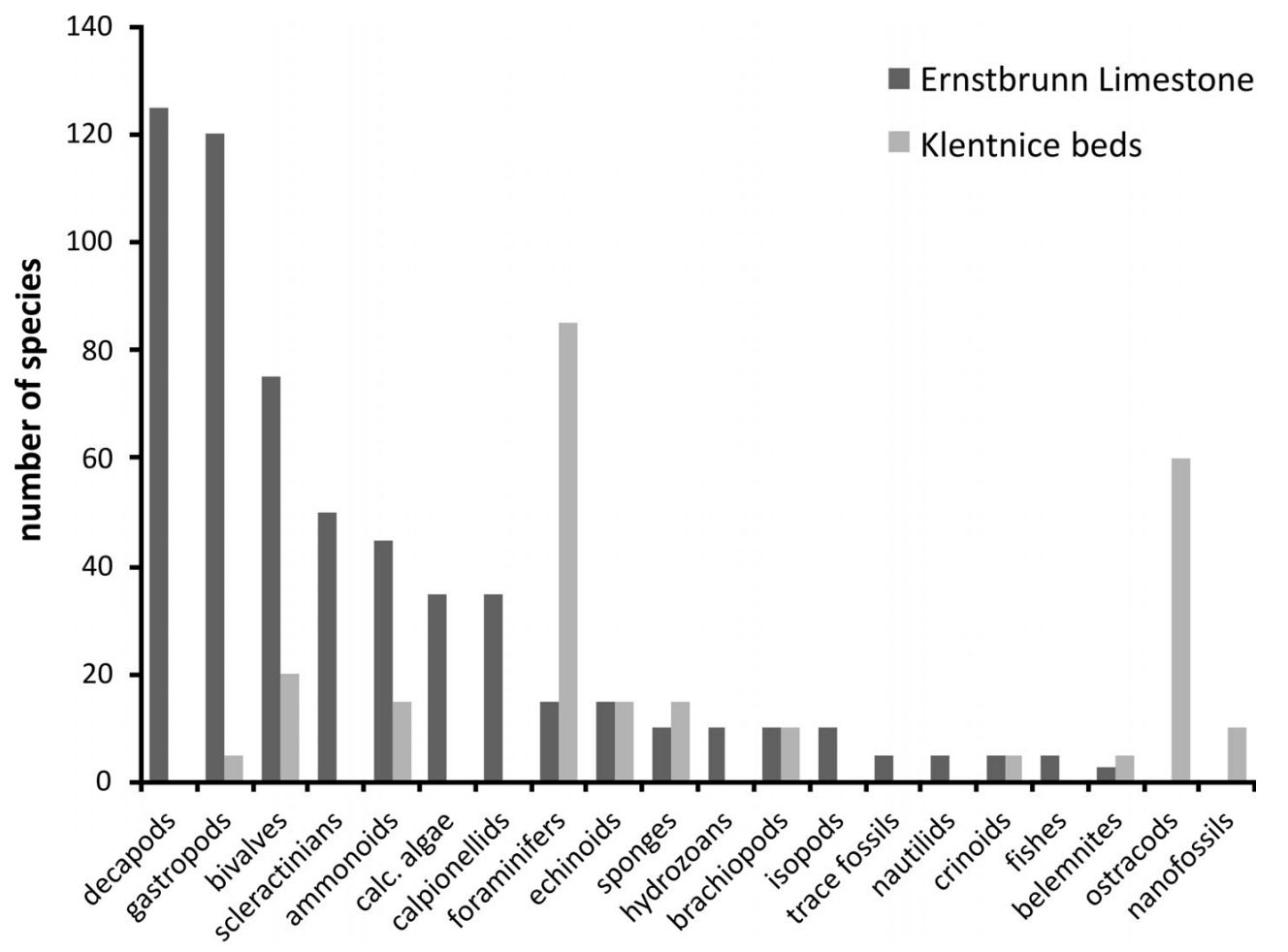

Figure 7. Bar chart showing estimated numbers of species for higher taxonomic groups occurring in the Ernstbrunn Limestone and Klentnice beds. Estimates are based on literature and collection surveys.

Scleractinia. - Moeller (1911) described 29 taxa of corals from the Ernstbrunn Limestone, but did not provide figures. A single coral from the Ernstbrunn Limestone of Staatz was reported by Kühn (1939). Only a small portion of the rich fauna of Scleractinia from the Ernstbrunn Limestone (Fig. 8H) has been studied by Eliášová (1986, 1990), since she solely considered material from localities in the Czech Republic. Although the major outcrops of this unit do not preserve proper coral reefs, corals must have occurred in small patch reefs (Eliášová 1986) or in non-biohermal assemblages, because they are present in considerable abundance and diversity. The now restored outcrop at Klafterbrunn likely exposed a proper coral reef (as interpreted by Bachmayer 1940) or at least its parautochthonous debris, since samples from this locality are predominantly composed of several taxa of well-preserved branching Scleractinia.

Bivalvia. - Epidiceratid bivalves were the first fossils to be described and figured from the Ernstbrunn Limestone (Haidinger 1782) and represent the dominant macrofossils of the epidiceratid-nerineid facies at Dörfles (Fig. 1A, B).
They were mentioned by numerous authors working on the stratum, and figured by several of them (e.g., Hofmann 1992b, Plöchinger \& Karanitsch 2002, Wessely 2006). An overview of the bivalve fauna was given in the unpublished theses of Dürrmayer (1931), who identified 24 taxa, and Bachmayer (1940), who extended this list to 35. Moreover, Bachmayer (1948a) speculated about the mode of life of the Epidiceratidae from Ernstbrunn. A survey of the material stored at the NHMW revealed approximately 70 species of Bivalvia (Fig. 8C, G).

Due to the loss of aragonite, the bivalve fauna of the Klentnice beds is usually restricted to oysters and pectinids. In places, however, relatively well-preserved, mainly infaunal bivalves occur, which may reach a diversity of some 20 species (personal observation SS). A few bivalves from the Klentnice beds at Niederfellabrunn have been reported by Abel (1897), who also described a new propeamussiid species. Furthermore, he recorded a species of "Aucella", which is a junior synonym of Buchia, a genus that is regarded a typical constituent of boreal Upper Jurassic faunas (e.g., Kelly 1990). Together with several new

Figure 8. Typical fossils from the Ernstbrunn Limestone. • A - Metriomphalus transitorius (Zittel, 1873); rubber cast of external mould; Dörfles; NHMW 2012/0108/0005. • B - Gastrodorus neuhausense von Meyer, 1864; specimen figured by Feldmann \& Schweitzer (2009, fig. 3.8); Dörfles; NHMW 1990z0041/4244. • C - Fimbria sp., internal mould. Dörfles; NHMW 2012/0108/0004. • D - Kutekiceras aff. steinbergense Zeiss, 2001; microconch; rubber cast of external mould; Dörfles; NHMW 2012/0108/0001. • E - Eunerinea hoheneggeri (Peters, 1855); original of Wieczorek (1997, pl. 1, fig. 8); Dörfles?; NHMW 1997z/0166/0005. • F - Lepidotes maximus Wagner, 1863; pharyngeal tooth; Falkenstein; NHMW 2012/0109/0001. • G - Chlamys cf. textoria (von Schlotheim, 1820); Dörfles; NHMW 2012/0108/0007. • H - indeterminable colonial coral; internal mould; Dörfles I quarry; NHMW 2012/0110/0003. • I - nerineid gastropod; internal mould; Dörfles; NHMW 2012/0108/0003. Scale bars: A, C-I = 10 mm; B = 1 mm. 


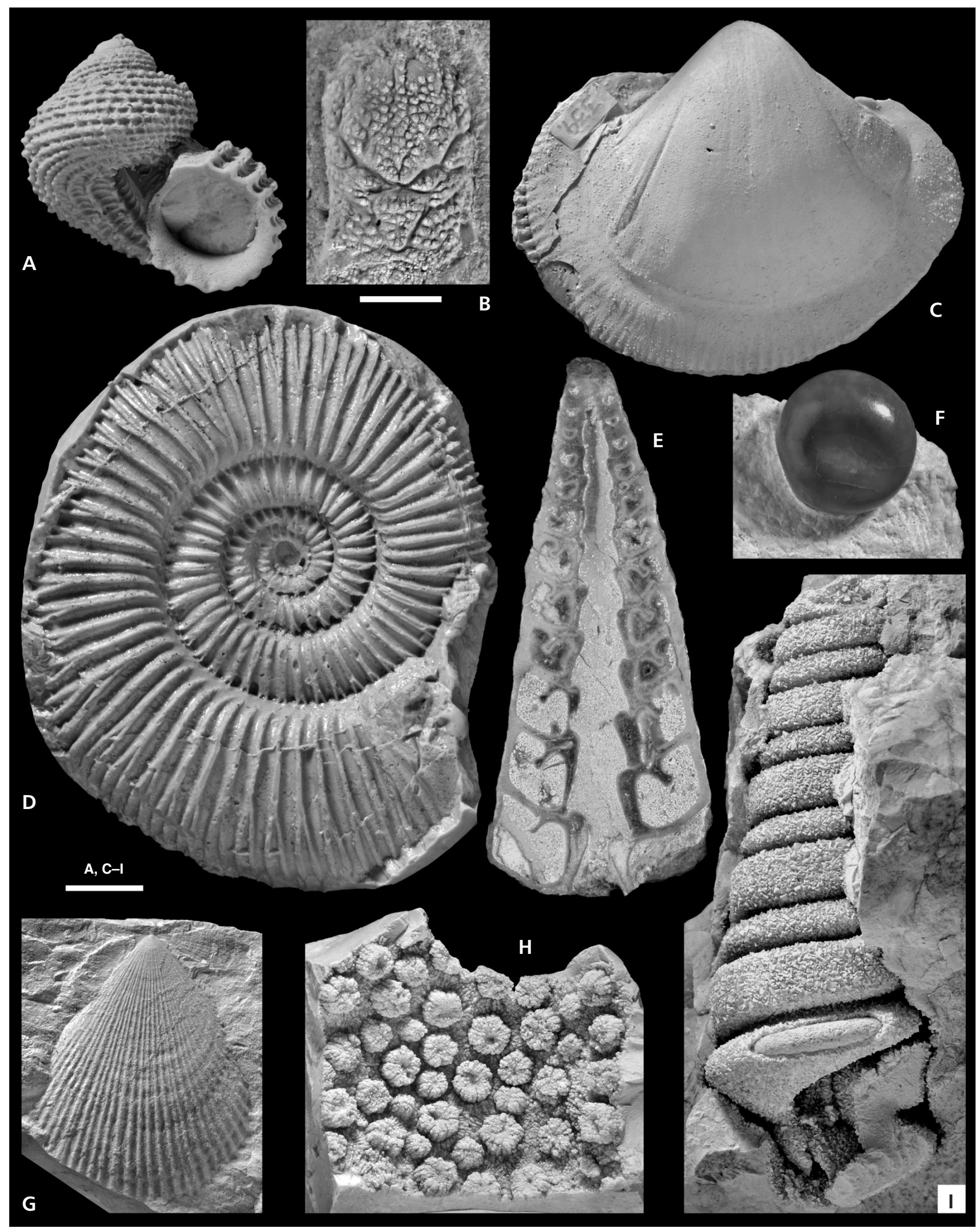


discoveries, these specimens were redescribed and refigured by Vetters (1905). Vašíček (1971) documented nuculoid and gryphaeid bivalves from drill cores penetrating the autochthonous Klentnice beds below the AlpineCarpathian Foredeep in the Czech Republic.

Gastropoda. - The largest fossils preserved in the Ernstbrunn Limestone are the more than $250 \mathrm{~mm}$ high Leviathania gigantea (Makowsky, 1874), which were first described from the Pavlov Hills (Makowsky 1874), figured by several authors (e.g., Bachmayer 1964b, 1969; Plöchinger \& Karanitsch 2002; Wessely 2006), and recently revised by Harzhauser \& Schneider (accepted). Most abundant, however, are nerineid gastropods (Fig. 8E, I), several taxa of which were recorded from the Ernstbrunn Limestone of the Mikulov area by Peters (1855). Recently, the nerineids from the Ernstbrunn-Dörfles quarries have been revised by Wieczorek (1998), who recognised 16 species. The total number of 45 gastropod species described by Dürrmayer (1931) was raised to 52 by Bachmayer (1940). The gastropod fauna of the Ernstbrunn Limestone (Fig. 8A) still awaits a comprehensive description, which would likely more or less double the number of species.

Because aragonitic shells have usually been dissolved, no gastropods have been recorded from the Klentnice beds so far, but a few unspecific internal moulds of turreted shells from Südmährerkreuz (see Fig. 4 for location) are stored in the collections of the NHMW.

Cephalopoda. - Altogether, four species of nautilids (Hercoglossa spp.) have been reported from the Ernstbrunn Limestone (Bachmayer 1940, 1957; Dürrmayer 1931). An exceptionally well preserved specimen was figured by Bachmayer (1964b, 1969). The ammonite fauna of the Ernstbrunn Limestone was revised by Zeiss (2001), who also provided a review of earlier work dealing with these fossils. These are the unpublished theses of Moeller (1911), Dürrmayer (1931), and Bachmayer (1940), as well as the fauna listed by Bachmayer (1957) and Zeiss \& Bachmayer (1989). Altogether, Zeiss (2001) reported 37 species of ammonites in 14 genera from Dörfles Werk II quarry (Fig. 8D), and a single specimen of Ernstbrunnia from the Galgenberg. Additionally, he recognised 13 more or less dubious taxa from the literature, where specimens have been lost. The most celebrated ammonite from the Ernstbrunn Limestone is Ernstbrunnia fasciculata Zeiss, 2001, since it was figured on a stamp issued on the occasion of the $100^{\text {th }}$ anniversary of the Naturhistorisches Museum Wien in 1976 (Bachmayer 1976, Thenius \& Vavra 1996) and formed the template of a logo of the Naturhistorisches Museum Wien in the 1980s. The specimen was refigured by Hofmann (1995) and Wessely (2006).

Ammonites from the Klentnice beds, namely from the surroundings of Niederfellabrunn, have been described by Abel (1897), Krafft (1897, dealing with a single specimen), Vetters (1905), Spath (1933), and Arkell (1956). Additionally, Vašíček $(1971,1980)$ detailed several species from boreholes in southern Moravia. The latest revision of the fauna was produced by Zeiss (1977) and recollected by Kutek \& Zeiss (1988). Additionally, several types of aptychi from outcrops and drill cores were detailed (Bachmayer 1963; Vašíček 1971, 1980; Vetters 1905).

Furthermore, Abel (1897) lists several belemnite species from the Klentnice beds of Niederfellabrunn, but does not provide figures. From the same outcrops, Vetters (1905) reported on five species of belemnites and described and illustrated three of them as new.

Brachiopoda. - A few brachiopods from the Ernstbrunn Limestone are listed by Prinzinger (1851). Suess (1858) mentions three species from the Ernstbrunn Limestone (one from Ernstbrunn and two from Mikulov) and four from the Klentnice beds. Dürrmayer (1931) lists a single species from the Ernstbrunn Limestone. Large terebratulids are relatively common at Dörfles V quarry, but have never been studied. Brachiopods from the Klentnice beds (Fig. 9A, H) are also mentioned by Hoernes (1874). Vetters (1905) described and illustrated three species of terebratulids, while Jüttner (1922) provided figures of a single rhynchonellid taxon.

Ostracoda. - Ostracods have so far only been recorded from the Klentnice beds of a single outcrop in the Mikulov region. In two papers Pokorný $(1959,1971)$ provided preliminary results on the ostracod fauna from this locality and formally described a new genus and a new species. Subsequently, Pokorný (1973) monographed the Ostracoda and recorded a total of 56 species.

Figure 9. Typical fossils from the Klentnice beds. • A - terebratulid brachiopod; Klentnice (Table Mountain); NHMW 1931/0001/0041. • B-J - all specimens (presumably) from Ernstbrunn (Semmelberg). B - Corynella sp.; NHMW 2012/0107/0007. • C - Acropeltis aequituberculatus L. Agassiz in L. Agassiz \& Desor, 1846, aboral view; NHMW 2012/0107/0002. • D - millericrinid pluricolumnal, articular surface; NHMW 2012/0107/0004. - E-Hemicidaris (Sphaerotiaris) sp. [= Hemicidaris crenularis auctt.]; lateral view of spine; NHMW 2012/0107/0005. • F-millericrinid pluricolumnal, lateral view; with serpulid (lower left); NHMW 2012/0107/0006. • G - Plegiocidaris crucifera (L. Agassiz, 1840); oral view; NHMW 2012/0107/0001. - H - rhynchonelliform brachiopod; NHMW 2012/0107/0009. • I - calcareous sponge; NHMW 2012/0107/0003. • J - calcareous sponge; polished section; NHMW 2012/0107/0008. Scale bars $=10 \mathrm{~mm}$. 


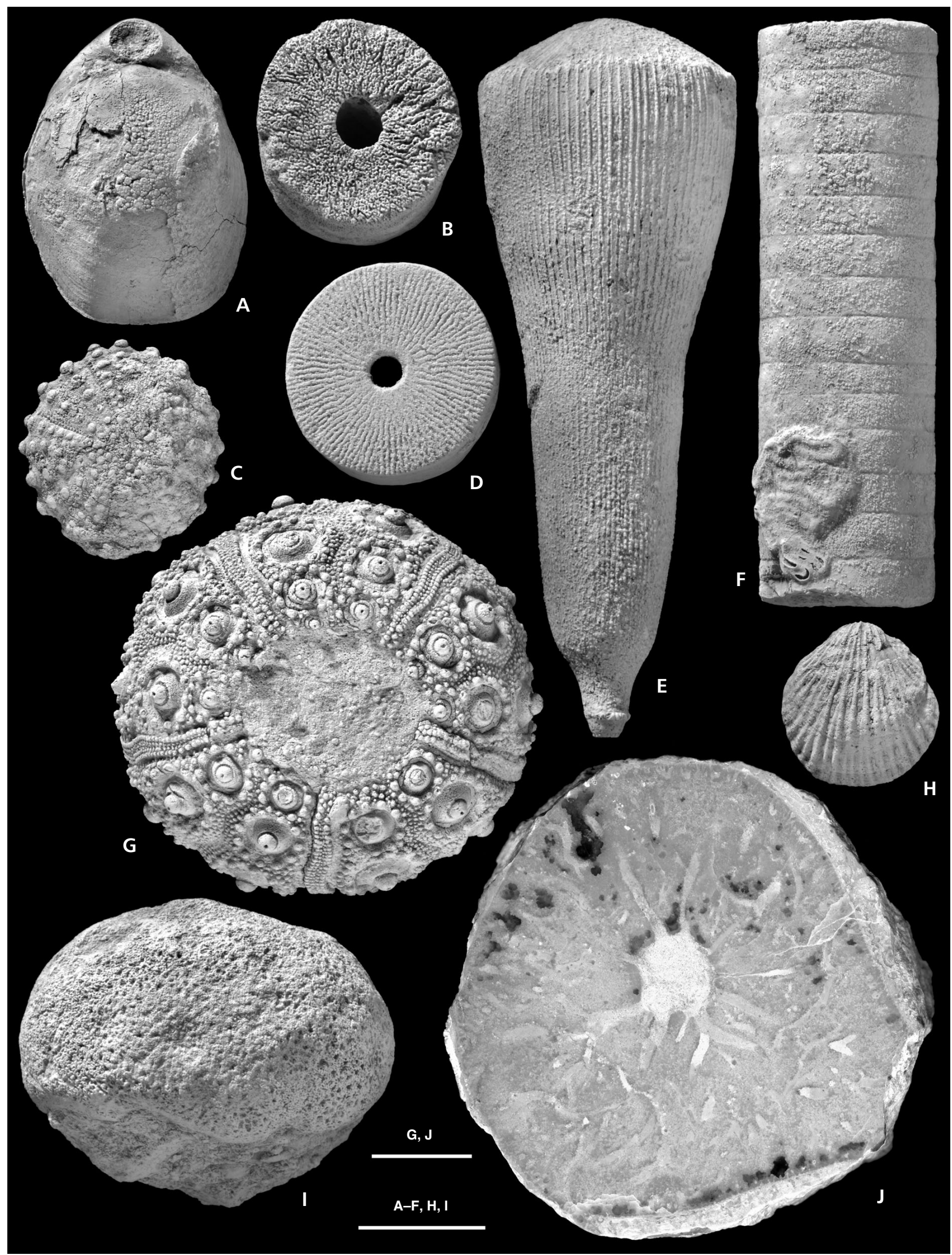


Isopoda. - Bachmayer (1949) described three species of Isopoda from the Ernstbrunn Limestone, including a new genus and two new species. Two additional species were newly established by Bachmayer (1955b) and the total number of isopods was updated to seven taxa.

Decapoda. - The first decapod species from the Ernstbrunn Limestone has been listed by Moericke (1897). Later, Glaessner (1931) and Bachmayer $(1945,1955 \mathrm{c})$ provided more or less comprehensive lists of crustaceans. Moreover, Bachmayer (1948b) reported on teratologic decapod specimens. Bachmayer (1958b, 1959) described a single new decapod. Wehner (1988) mentioned several taxa from Ernstbrunn in her Ph.D. thesis on the "Prosopidae" (Brachyura). A few years ago, the several thousands of carapaces collected by Friedrich Bachmayer during four decades were "rediscovered" in the collections of the NHMW Vienna and a wealth of species was treated in numerous publications since then (Feldmann \& Schweitzer 2009; Robins et al. 2007, 2010, 2012, 2013; Schweitzer \& Feldmann 2008a, b, 2009a-d, 2010a-d). Nevertheless, numerous additional forms are hitherto unpublished.

Echinodermata. - The first short list of echinoderms from the Ernstbrunn Limestone was provided by Prinzinger (1851). Much later, Bachmayer (1958a) reported two crinoid species, one of them described as new. Remains of Saccocoma were mentioned from Tithonian strata from a borehole by Rehánek (1987a). Besides, the Ernstbrunn Limestone yields a moderately diverse fauna of echinoids, including exceptionally large "regular" and irregular taxa. From the Klentnice beds, Rolle (1855) describes 9 species of "regular" echinoids. Moreover, crinoids and echinoids from the Klentnice beds are listed by Hoernes (1874) and Jüttner (1922), who also figures several species. Within this unit large hemicidarid spines (Fig. 9E) are most common, as are stem fragments of millericrinid crinoids (Fig. 9D, F). Apart from Plegiocidaris (Fig. 9G) other echinoderm remains (Fig. 9C) are generally rare.

Pisces. - Dürrmayer (1931) and Bachmayer (1940) list a single species of fish, i.e. Lepidotes maximus Wagner, 1863. The typical circular teeth of these large fishes occur in high abundance at Falkenstein (Fig. 8F) and were obviously also quite common in particular outcrops of the Mikulov region, judging from old collections at Vienna (NHMW, GBA). Occasionally, the teeth are preserved more or less in situ, while the bony parts of the skeleton disintegrated entirely during diagenesis. Several small pharyngeal teeth of unknown affinity and a few poorly preserved shark teeth are present in the collections of NHMW.

\section{Significance of the biota}

Anybody having a close look at the "classical" Ernstbrunn Limestone, i.e. the lagoonal facies of Dörfles, Falkenstein, or Marienmühle at outcrop will easily recognize the outstanding palaeontological significance of this stratum, simply because of its unusual richness in fossils (Fig. 7). Looking at detail, the assemblage yields not just an enormous number of partly remarkably large specimens but also an extraordinarily high diversity. Estimated to comprise more than 500 species (Bachmayer 1957), the fossil assemblage of the Ernstbrunn Limestone ranges among the most speciose Mesozoic environments ever recorded and certainly deserves to be termed an Upper Jurassic marine biodiversity hotspot (sensu Roberts et al. 2002; Fig. 7). However, up to the $21^{\text {st }}$ century, this has largely remained "hidden diversity", since despite of more than 40 years of intense, enthusiastic, and accurate collecting by Bachmayer none of the most specious groups of fossils was detailed. First and most important from a stratigraphical point of view, the ammonites of the Ernstbrunn Limestone were monographed (Zeiss 2001). Recently, the decapod faunas from Ernstbrunn-Dörfles (represented by more than 10.000 specimens in the collections of the NHMW) and from the coeval Štramberk Limestone (Silesian Unit, northern Moravia, Czech Republic) have been found to be of extraordinary significance for phylogenetic studies. The Tithonian reefs and reef-associated strata at the northern Tethys margin may comprise an ancient radiation centre of the Decapoda and accordingly acted as a cradle for several major clades of modern crabs (Feldmann \& Schweitzer 2009; Schweitzer \& Feldmann 2008a, b, 2009a-d, 2010a-d). Likewise, the Jurassic-Cretaceous lagoons on the Tethys shelf may have played a key role in the development of the Requienioidea, i.e. the left-valve-attached clade of rudist bivalves (Hippuritida). Basal representatives of this group, now placed in the family Epidiceratidae (Bieler et al. 2010), flourished in the lagoons of the Ernstbrunn-Pavlov Carbonate Platform, forming small, paucispecific patch reefs. Together with the highly abundant Nerineidae (Gastropoda), which also came to bloom during the Tithonian-Berriasian, and with a rich flora of dasyclad algae, the Epidiceratidae dominate the biofacies of these lagoons.

Although the fossil assemblage preserved in the Klentnice beds is much less spectacular due to the nearcomplete diagenetic loss of aragonite, the stratum is wellknown for its more or less strongly silicified, originally calcitic skeletons, i.e. mainly echinoderms, brachiopods, and calcareous sponges. At places ammonites or bivalves add to a more complex view of the fauna, providing valuable insight into bottom life of the outer shelf area dominated by silciclastic sediments.

Information on inner and outer platform carbonates (= Ernstbrunn Limestone) and on their intergrading with 
siliciclastic sediments of the outer shelf (= Klentnice beds, Mikulov Marls, Kurdějov Arenite) is available from several localities at surface and numerous cores. As a whole, they offer an exceptionally complete view on the facies architecture on and around a Tithonian-Berriasian marginal carbonate platform in the Tethys Ocean.

Strata of similar age and composition are fairly restricted in occurrence but geographically widespread, which increases the scientific importance of the Jurassic-Cretaceous klippen of the WZU. A coeval highly diverse assemblage has been reported from the Stramberk Limestone, cropping out in several klippen associated with the Silesian and Subsilesian nappes of the Carpathians in the Stramberk (NE Czech Republic) and Andrychow (S Poland) regions (e.g., Boehm 1883; Zittel 1868, 1873). However, the Stramberk Limestone predominantly preserves near-shore strata, and the more distal facies, well-known from the Ernstbrunn Limestone and Klentnice beds, is lacking. Lagoonal fossil assemblages of similar age, diversity, and composition have been described from Mont Salève (Hauté-Savoie, SE France; e.g., Joukowsky \& Favre 1913), Valfin (W Switzerland, Loriol \& Bourgeat 1886-1888), southern Ukraine (Alth 1881, 1882) and the Crimea peninsula (e.g., Pčelinzev 1924, 1963). Slightly older, Lower Tithonian assemblages are reported from the Palermo region (Sicily, Italy; Gemmellaro 1868-1876) and the southern Franconian Alb (Kelheim and Ingolstadt regions; e.g., Boehm 1882). Most of these outcrops were less intensely sampled and/or are significantly smaller than the Ernstbrunn, Falkenstein and Pavlov klippen, making the Ernstbrunn Limestone one of the most important strata for exploration of these facies and their typical biota.

\section{Future directions}

Due to intensive drilling in the course of hydrocarbon exploration, knowledge of the standard geologic succession of the Upper Jurassic rocks at the southern slope of the Bohemian Massif and the tectonic evolution of the WZU klippen seem largely settled. With regard to sedimentology, a next crucial step would be a comprehensive study of the (micro-)facies of all major and minor outcrops of the Ernstbrunn Limestone, in order to identify the total range of existing lithofacies and to develop a facies model. Additionally, outcrops and historical wine cellars exposing the Klentnice beds need to be systematically accessed and/or excavated in order to figure out stratification and sedimentology.

With regard to palaeontology, a systematic account of the Ernstbrunn fossil fauna and flora would be necessary, to establish a solid base for comprehensive studies of palaeoecology, palaeoclimatology and palaeobiogeography. Extensive collections of fossils are stored in the palaeontological repositories of the Natural History Museum Vienna and the Moravian Museum at Brno, and to a minor extent at the Geologische Bundesanstalt Wien, the University of Vienna, and the Krahuletz Museum at Eggenburg. Preliminary data from Bivalvia, which are usually reliable indicators of (palaeo-)ecology suggest close faunistic and ecologic relationships to the coeval Stramberk Limestone, but also indicate significant differences in community structure, which need to be evaluated in detail. Likewise, all other groups of fossil organisms may add important information about the Ernstbrunn ecosystem.

Finally, sedimentological and palaeontological data should be integrated to enable a preferably complete reconstruction of the (1) size and extent, (2) facies architecture, and (3) palaeoenvironment of the former Ernstbrunn-Pavlov Carbonate Platform. The resulting model may be compared to those from coeval carbonate platforms, in order to identify their typical as well as unique features. Finally, data may also be checked against those from earlier or later ecosystems of similar composition to distinguish directional from non-directional developments.

\section{Acknowledgements}

We owe sincere thanks to the following people and organisations: Thomas Hofmann (Geologische Bundesanstalt, Vienna) and Radek Vodrážka (Czech Geological Survey, Prague) made numerous rare publications accessible. Fred Rögl (Natural History Museum Vienna), Fritz F. Steininger (Eggenburg) and Godfried Wessely (Vienna) provided information on regional geology. Ulla Schudack and Michael Schudack (both Freie Universität Berlin) provided information on micropalaeontology. Oleg Mandic (Vienna) provided the photograph for Figure 5F. Alice Schumacher (Natural History Museum Vienna) photographed the fossils depicted in Figures 1, 8 and 9. Irene Zorn (Geologische Bundesanstalt, Vienna) and Karl Rauscher (University of Vienna) enabled access to the collections under their care. Petr Skupien (Vysoká škola báňská, Technická univerzita, Ostrava, Czech Republic) organised and guided a highly informative field trip to the Štramberk region attended by SS Careful reviews by István Fớzy (Hungarian Natural History Museum, Budapest) and Matúš Hyžný (Department of Geology and Palaeontology, Comenius University, Bratislava) helped to significantly improve the manuscript. The work of SS was financially supported by the Deutsche Forschungsgemeinschaft (DFG research fellowship SCHN 1264/1-1).

\section{References}

As far as we are aware, this bibliography covers all aspects of geoscientific research particularly concerned with the Ernstbrunn Limestone and Klentnice beds at surface and subsurface. Furthermore, compilations of regional geology (e.g., Andrusov 1959; Cicha et al. 1964; Fuchs 1976; Hauer 1875, 1878; Kober 1926; 
Kohn 1911; Neumayr 1870, 1887; Oberhauser 1980; Paul 1898; Pícha et al. 2006; Rasumovsky 1830, 1831; Roth 1980; Roth \& Hanzlíková 1968; Rzehak 1902-1903; Seifert 1993; Stejskal 1935a; Straník et al. 1999; Thenius 1974; Uhlig 1907; Zapfe 1963), geologic maps and mapping reports (Abel 1910; Abel et al. 1907; Bachmayer 1954b, 1955a; Beck et al. 1980; Čtyroký et al. 1988, 1995; Glocker 1842; Grill 1952, 1958, 1961, 1962, 1968; Grill \& Küpper 1954; Hauer 1869; Jüttner 1940; Kolenati 1852; Matějka 1963; Partsch 1844; Roetzel 2002; Schnabel 2002; Vetters 1910), excursion guides (Bachmayer \& Grill 1958; Grill \& Kapounek 1964; Grill et al. 1963; Hofmann 1992b, 1997; Rögl et al. 2009; Sauer et al. 1992), and a few popular articles (Bachmayer 1954a, 1964b, 1969; Hofmann 1995; Kroh 2010; Plöchinger \& Karanitsch 2002; Schneider 2012; Stojaspal 1984) and abstracts (e.g., Poul \& Melichar 2003, 2005, 2006; Schneider et al. 2011) are included. Certainly, the Ernstbrunn Limestone and Klentnice beds are mentioned in additional textbooks or larger scale geologic overviews, which are not considered herein, since they only comprise secondary sources rarely adding new data. If not indicated otherwise (= [not seen]), all publications have been personally checked by the authors. Any information on significant contributions supplementary to this list is highly welcome!

Abel, O. 1897. Die Tithonschichten von Niederfellabrunn in Niederösterreich und deren Beziehungen zur unteren Wolgastufe. Verhandlungen der Kaiserlich-königlichen geologischen Reichsanstalt 1897, 343-362.

ABEL, O. 1899a. Studien im Klippengebiete zwischen Donau und Thaya. I. Pollau-Schweinbarth (Aufnahmsbericht). Verhandlungen der Kaiserlich-königlichen geologischen Reichsanstalt 1899, 284-287.

ABEL, O. 1899b. Die Beziehungen des Klippengebietes zwischen Donau und Thaya zum alpin-karpathischen Gebirgssysteme. Verhandlungen der Kaiserlich-königlichen geologischen Reichsanstalt 1899, 374-381.

ABEL, O. 1910. Erläuterungen zur Geologischen Karte der Österreichisch-Ungarischen Monarchie, Blatt Auspitz und Nikolsburg. 40 pp. Kaiserlich-königliche geologische Reichsanstalt, Wien.

Abel, O., Paul, C.M. \& Tausch, L. von 1907. Geologische Spezialkarte der im Reichsrate vertretenen Königreiche und Länder der österreichisch-ungarischen Monarchie. NW.Gruppe Nr. 85. Auspitz und Nikolsburg. 1:75 000. Kaiserlich-königliche Geologische Reichsanstalt, Wien.

ADÁmeK, J. 1979. Plynové ložisko Dolní Dunajovice a geologická stavba jižní části karpatské předhlubně. Zemný plyn a nafta 24, $1-22$.

ADÁMEK, J. 1986. Geologické poznatky o stavbě mezozoika v úseku JIH jihovýchodních svahů Českého masívu. Zemný plyn a nafta 31, 453-484.

AdÁmeK, J. 2005. The Jurassic floor of the Bohemian Massif in Moravia - geology and paleogeography. Bulletin of Geosciences 80, 291-305.

Adelung, J.C. 1796. Grammatisch-kritisches Wörterbuch der Hochdeutschen Mundart mit beständiger Vergleichung der übrigen Mundarten, besonders aber der Oberdeutschen. Zweyter Theil, von $F-L .2^{\text {nd }}$ edition. 2141 pp. J.G.I. Breitkopf, Leipzig.
Agassiz, L. 1840. Description des Échinodermes fossiles de la Suisse; Seconde partie. Cidarides. Mémoires de la Société helvétique des Sciences naturelles 4, i-iv, 1-97.

Agassiz, L. \& Desor, P.J.E. 1846. Catalogue raisonné des familles, des genres, et des espèces de la classe des échinodermes. Annales des Sciences Naturelles, Troisième Série, Zoologie 6, 305-374.

Alth, A. 1881. Wapień niżniowski i jego skamieliny. Pamiętnik Akademii Umiejętności w Krakowie, Wydzial MatematycznoPrzyrodniczy 6, 1-160. [page numbers from reprint]

Alth, A. von 1882. Die Versteinerungen de Niżniower Kalksteines. Beiträge zur Paläontologie Österreich-Ungarns und des Orients 1, 183-332.

ANDRUSOv, D. 1959. Geológia československých Karpát. Zväzok II. 375 pp. Vydavatel'stvo Slovenskej akadémie vied, Bratislava.

ARKelL, W.J. 1956. Jurassic geology of the world. 806 pp. Oliver and Boyd, Edinburgh \& London.

BACHMAYER, F. 1940. Beiträge zur Kenntnis der Tithonfauna aus dem Raume von Ernstbrunn (Niederdonau). 73 pp. Ph.D. thesis, University of Vienna, Austria.

BACHMAYER, F. 1944 [for 1940-1941]. Zwei neue Siphonea verticillatae aus dem Jurakalk von Dörfles und Klafterbrunn (Nieder-Donau). Verhandlungen der Zoologisch-Botanischen Gesellschaft 90/91, 237-240.

Bachmayer, F. 1945. Die Crustaceen aus dem Ernstbrunner Kalk der Jura-Klippenzone zwischen Donau und Thaya. Jahrbuch der Geologischen Bundesanstalt 1945, 35-43.

BACHMAYER, F. 1948a. Neue Untersuchungen über Diceraten aus dem „Ernstbrunner Kalk“. Annalen des Naturhistorischen Museums Wien 56, 564-568.

BACHMAYER, F. 1948b. Pathogene Wucherungen bei jurassischen Dekapoden. Sitzungsberichte der Österreichischen Akademie der Wissenschaften, Mathematisch-naturwissenschaftliche Klasse, Abteilung I 157(6-10), 263-266.

BACHMAYer, F. 1949. Zwei neue Asseln aus dem Oberjurakalk von Ernstbrunn. Sitzungsberichte der Österreichischen Akademie der Wissenschaften, Mathematisch-naturwissenschaftliche Klasse, Abteilung I 158(4), 263-271.

BACHMAYER, F. 1954a. Ein Korallenriff in Niederösterreich. Universum 1954(15), 461-468.

BACHMAYER, F. 1954b. Bericht über Kartierungsarbeiten im Bereich der Waschbergzone (Jura - Kreide - Klippen) auf den Blättern Mistelbach (24) und Poysdorf (25). Verhandlungen der Geologischen Bundesanstalt 1954, 19-21.

BACHMAYER, F. 1955a. Bericht über Kartierungsarbeiten im Bereich der Waschbergzone (Mesozoikum der Klippenzone) auf den Blättern Mistelbach (24) und Stockerau (40). Verhandlungen der Geologischen Bundesanstalt 1955, 11-13.

Bachmayer, F. 1955b. Die fossilen Asseln aus den Oberjuraschichten von Ernstbrunn in Niederösterreich und Stramberg in Mähren. Sitzungsberichte der Österreichischen Akademie der Wissenschaften, Mathematisch-naturwissenschaftliche Klasse, Abteilung I 164, 255-273.

BACHMAYER, F. 1955c. Die Crustaceenfauna der tithonischen Riffkalke von Ernstbrunn und Stramberg. Paläontologische Zeitschrift 29, 5-6.

BACHMAYeR, F. 1957. Das Mesozoikum der niederösterreichischen Klippen. Zeitschrift der Deutschen Geologischen Gesellschaft 109, 659-660. 
Bachmayer, F. 1958a. Pseudosaccocoma (Crinoidea) aus dem Korallenriffkalk (Obermalm) von Ernstbrunn (Niederösterreich). Paläontologische Zeitschrift 32, 40-51.

BACHMAYER, F. 1958b. Ein bemerkenswerter fossiler Krebsrest aus dem Jurakalk von Ernstbrunn (Niederösterreich). Veröffentlichungen aus dem Naturhistorischen Museum, Neue Folge 1, 16.

BACHMAYER, F. 1959. Ein bemerkenswerter fossiler Krebsrest aus dem Jurakalk von Ernstbrunn (Niederösterreich). Universum 1959(1), 25.

Bachmayer, F. 1963. Beiträge zur Palaeontologie oberjurassischer Riffe. I. Die Aptychen (Ammonoidea) des Oberjura von Stramberg (ČSR). II. Die Aptychen der Klentnitzer Serie in Österreich. Annalen des Naturhistorischen Museums Wien 66, 125-138.

BACHMAYER, F. 1964a. Untersuchung einer Kluftfüllung im Steinbruch Staatz (Kautendorf), nördliches Niederösterreich. Annalen des Naturhistorischen Museum Wien 66, 181-187.

BACHMAYER, F. 1964b. Ein Korallenriff in Niederösterreich, 102-111. In BaChMayer, F., CoRnelius-Furlani, M., KaMPTner, E., Kirnbauer, F., Kollmann, H.A. \& Zapfe, H. Schätze im Boden. Bilder aus Österreichs geologischer Vergangenheit. Veröffentlichungen aus dem Naturhistorischen Museum, Neue Folge 5, $1^{\text {st }}$ edition.

BACHMAYER, F. 1969. Ein Korallenriff in Niederösterreich, 115-124. In Bachmayer, F., Cornelius-Furlani, M., Kamptner, E., Kirnbauer, F., Kollmann, H.A. \& Zapfe, H. Schätze im Boden. Bilder aus Österreichs geologischer Vergangenheit. Veröffentlichungen aus dem Naturhistorischen Museum, Neue Folge 5, $2^{\text {nd }}$ edition.

BACHMAYER, F. 1976. Sonderpostmarke Naturhistorisches Museum Wien, Jubiläumsausstellung 1976.8 pp. Österreichische Staatsdruckerei, Wien.

BachmaYer, F. \& Flügel, E. 1961a. Die Hydrozoen aus dem Oberjura von Ernstbrunn (Niederösterreich) und Stramberg (ČSR). Palaeontographica, Abteilung A 116, 122-143.

BaChMaYer, F. \& FlÜGEL, E. 1961b. Die „Chaetetiden“ aus dem Oberjura von Ernstbrunn (Niederösterreich) und Stramberg (ČSR). Palaeontographica, Abteilung A 116, 144-174.

BACHMAYER, F. \& GRILl, R. 1958. Exkursion $\mathrm{H}_{5}$ : Waschbergzone (äußere Klippenzone). Exkursionsführer zur Tagung der Geologischen Gesellschaft Wien 1958, 1-8.

Beck, H., Spengler, E., Vetters, H., WaAgen, L. \& Winkler, A. 1980. Geologische Karte der Republik Österreich und Nachbargebiete. Geologische Bundesanstalt, Wien.

Bieler, R., CARTER, J.G. \& CoAN, E.V. 2010. Classification of bivalve families, 113-133. In Bouchet, P. \& RocroI, J.-P. Nomenclator of bivalve families. Malacologia 52(2).

Bozнм, G. 1882. Die Fauna des Kelheimer Diceras-Kalkes. Zweite Abtheilung: Bivalven. Palaeontographica 28, 141-192 [67-118].

Bоенм, G. 1883. Die Bivalven der Stramberger Schichten. Palaeontographica, Supplement 2(4), 493-680.

BouÉ, A. 1829. In LeONHARD, C.C. von (ed.) Geognostisches Gemälde von Deutschland. Mit Rücksicht auf die GebirgsBeschaffenheit nachbarlicher Staaten. 623 pp. J.C. Herrmann'sche Buchhandlung, Frankfurt am Main.

BouÉ, A. 1830. Résumé des observations sur l'age relatif des dépots secondaires dans les Alpes et les Carpathes. Journal de Géologie 1, 50-86.
Brix, F. \& Götzinger, K. 1964. Die Ergebnisse der Aufschlußarbeiten der ÖMV AG in der Molassezone Niederösterreichs in den Jahren 1957-1963. Teil I. Zur Geologie der Beckenfüllung, des Rahmens und des Untergrundes. Erdöl-Zeitung $80,57-76$.

Brix, F., KRÖll, A. \& Wessely, G. 1977. Die Molassezone und deren Untergrund in Niederösterreich. Erdöl-Erdgas-Zeitschrift, Special issue 93, 1-35.

Bukry, D. 1973. Low-latitude coccolith biostratigraphic zonation. Initial Reports, Deep Sea Drilling Project 15, 685-703.

Bullinger, E. 1997. Die Bedeutung des Ernstbrunner Kalkes für die Industrie. Exkursionsführer, Österreichische Geologische Gesellschaft 17, 37-38.

Cíha, I., Chmelík, F., Pícha, F. \& Stráník, Z. 1964 [for 1963]. Übersicht über den heutigen Stand der Forschungen in der Molassezone Ždánicer und Pouzdřaner Einheit Süd-Mährens. Mitteilungen der Geologischen Gesellschaft Wien 56, 445-468.

Č́tyroký, P., Havlíček, P., Dornič, J., Stráník, Z. \& Zeman, A. 1988. Základní geologická mapa ČSSR. List 34-142 Mikulov. Ústřední ústav geologický, Praha.

ČTyroký, P., Havlíček, P., Stráník, Z. \& PÁlenský, P. 1995. Geologická a př́rodovědná mapa CHKO a BR Pálava. Geologische und naturwissenschaftliche Karte des Landschaftsschutzgebietes (CHKO) und des Biosphärenreservates (BR) Pálava. $1: 25.000$. Český geologický ústav, Praha.

Defrance, J.L.M. 1819. Dicerate. (Foss.), 177-178. In Dictionnaire des Sciences naturelles. Tome treizième. DEA-DZW. F.G. Levrault, Le Normant, Strasbourg \& Paris.

DürRmaYer, W. 1931. Die Fauna von Ernstbrunn. 175 pp. Ph.D. thesis, University of Vienna, Austria.

ELIÁš, M. 1962. Zpráva o sedimentárně petrografickém výzkumu klentnických vrstev a ernstbrunnských vápenců. Zprávy o geologických výzkumech v roce 1961, 196-198.

ELIÁš, M. 1974. Mikrofaciální výzkum karbonátů naftonadějných oblastí na příkladě autochtonní jury jv. svahů Českého masívu. Zemný plyn a nafta 18, 359-374.

Eliáš, M. 1977. Paläogeographische Entwicklung des Mesozoikums und des Tertiärs am Rande der Karpaten und des Böhmischen Massivs. Erdöl-Erdgas-Zeitschrift 93, Sonderausgabe, 5-11. [not seen]

ELIÁš, M. 1981. Facies and paleogeography of the Jurassic of the Bohemian Massif. Sborník geologických věd, Geologie 35, 75-144.

Eliáš, M. 1992. Sedimentology of the Klentnice Formation and the Ernstbrunn Limestone (Ždanice-Subsilesian unit of the outer West Carpathians). Věstník Ústředního ústavu geologického / Bulletin of the Geological Survey, Prague 67, 179-193.

ELIÁš, M. \& Elíś̌̌ová, H. 1984. Facies and paleogeography of the Jurassic in the western part of the Outer Flysch Carpathians in Czechoslovakia. Sborník geologických věd, Geologie 39, 105-170.

EliáŠ, M. \& EliáŠovÁ, H. 1985. New biostratigraphic material from the Mesozoic of the Flysch Carpathians and their foreland. Věstník Ústředního ústavu geologického / Bulletin of the Geological Survey, Prague 60, 105-106.

EliÁš, M. \& Elí́šovÁ, H. 1986. Elevation facies of the Malm in Moravia. Geologický zborník 37, 533-550. 
Eliáš, M. \& Wessely, G. 1990. The autochthonous Mesozoic of the eastern flank of the Bohemian Massif - an object of mutual geological efforts between Austria and the ČSSR, 78-83. In MinǍ̌íkovÁ, D. \& LoBITZER, H. (eds) Thirty years of geological cooperation between Austria and Czechoslovakia. Federal Geological Survey, Geological Survey, Vienna \& Prague.

Elí́šovÁ, H. 1986. Korálová fauna ernstbrunnských vápenců (malm - spodní křída Pavlovských vrchů, ždánická jednotka vnějších flyšových Karpat. Zprávy o geologických výzkumech $\checkmark$ roce $1984,65-66$.

EliášovÁ, H. 1990. Coraux des calcaires d'Ernstbrunn (Jurassique superieur-Crétacé inférieur dans les Carpates externes, zone de Waschberg, Tchécoslovaquie). Časopis pro mineralogii a geologii 35, 113-133.

ERnStBRUNNER KALKTECHNIK GMBH 2011. Homepage, accessible from http://www.profibaustoffe.at/index.php?option=com content\&task=view\&id=48\&Itemid=86 [last accessed 01/2012].

FABIAN, H.J. \& JÜTTNER, K. 1937. Die Natur der Hornsteine aus dem oberen Jura der Pollauer Berge. Firgenwald 10, 29-31.

Feldmann, R.M. \& Schweitzer, C.E. 2009. Revision of Jurassic Homoloidea De Haan, 1839, from the Ernstbrunn and Stramberk limestones, Austria and the Czech Republic. Annalen des Naturhistorischen Museums Wien, Serie A 111, 183-206.

FERSTL VON FöRSTENAU, J. 1845. Geognostische Betrachtung der Nikolsburger Berge. 29 pp. Inaugural-Dissertation, University of Vienna. P.P. Mechitaristen, Vienna, Austria.

FoEtTERLE, F. 1853. Bericht über die geologische Aufnahme des südlichen Mähren. Jahrbuch der Kaiserlich-königlichen geologischen Reichsanstalt 4, 25-57.

FRIEDL, K. 1927. Über die jüngsten Erdölforschungen im Wiener Becken. Petroleum 1927(6), 1-52.

Fuchs, W. 1976. Gedanken zur Tektogenese der nördlichen Molasse zwischen Rhône und March. Jahrbuch der Geologischen Bundesanstalt 119, 207-249.

Gemmellaro, G.G. 1868-1876. Studi paleontologici sulla fauna del Calcare a Terebratula janitor del nord di Sicilia. VIII + 56 $+92+100$ pp. Stabilimento tipografico Lao, Palermo.

Glaessner, M.F. 1930. Die geologischen Verhältnisse des Kreidevorkommens zwischen Bruderndorf und Ernstbrunn (Niederösterreich), 526-533. In KüHN, O. (ed.) Das Danien der Äusseren Klippenzone bei Wien. Geologische und paläontologische Abhandlungen, Neue Folge 17.

Glaessner, M.F. 1931. Geologische Studien in der äußeren Klippenzone. Jahrbuch der geologischen Bundesanstalt Wien 81, 1-23.

GlaessNER, M.F. 1937. Die alpine Randzone nördlich der Donau und ihre erdölgeologische Bedeutung. Petroleum 33(43), 1-8.

GLOCKER, E.F. 1842. Beiträge zur geognostischen Kenntnis Mährens. Neues Jahrbuch für Mineralogie, Geognosie, Geologie und Petrefakten-Kunde 1842, 22-34.

Gramann, F. \& Luppold, F.-W. 1991. Zur Mikropaläontologie des Oberen Jura im Autobahn-Einschnitt Uppen, östlich Hildesheim, und der Grenze Korallenoolith-Kimmeridge in Niedersachsen. Geologisches Jahrbuch A 126, 197-233.

GRILL, R. 1952. Aufnahmen auf den Blättern Mistelbach (4557) und Tulln (4656), mit Anschlussbegehungen auf Blatt Hollabrunn (4556) (Bericht 1951). Verhandlungen der Geologischen Bundesanstalt 1952, 1-3.
GriLl, R. 1953. Der Flysch, die Waschbergzone und das Jungtertiär um Ernstbrunn (Niederöstereich). Jahrbuch der Geologischen Bundesanstalt 96, 65-116.

GrILL, R. 1958. Über den geologischen Aufbau des Außeralpinen Wiener Beckens. Verhandlungen der Geologischen Bundesanstalt 1958, 44-54.

GRILL, R. 1961. Geologische Karte des nordöstlichen Weinviertels. 1 : 75.000. Geologische Bundesanstalt, Vienna.

GRILL, R. 1962. Erläuterungen zur geologischen Karte der Umgebung von Korneuburg und Stockerau 1 : 50 000. 52 pp. Geologische Bundesanstalt, Vienna.

GRILL, R. 1963. Exkursion Inneralpines Wiener Becken nördlich der Donau, Molassegebiet und Waschbergzone. Exkursionsführer, 8. Europäisches Mikropaläontologisches Kolloquium, Österreich. Verhandlungen der Geologischen Bundesanstalt, Sonderheft F, 20-40.

GRILL, R. 1968. Erläuterungen zur geologischen Karte des nordöstlichen Weinviertels und zu Blatt Gänserndorf. 155 pp. Geologische Bundesanstalt, Vienna.

Grill, R. \& KapouneK, J. 1964. Exkursion II/1: Waschbergzone und Erdölfelder. Der Außenrand des alpin-karpatischen Gebirges bei Wien. Mitteilungen der Geologischen Gesellschaft in Wien 57, 147-155.

Grill, R., Kollmann, K., KüPPer, H. \& Oberhauser, R. (eds) 1963. Exkursionsführer, 8. Europäisches Mikropaläontologisches Kolloquium, Österreich. 92 pp. Geologische Bundesanstalt, Vienna.

GRILL, R. \& KÜPPER, H. (eds) 1954. Erläuterungen zur geologischen Karte der Umgebung von Wien. 138 pp. Geologische Bundesanstalt, Vienna.

GröschKe, M. 1985. Stratigraphie und Ammonitenfauna der Jurarelikte zwischen Straubing und Passau (Niederbayern). Palaeontographica, Abteilung A 191, 1-68.

Haidinger, K. 1782. Beschreibung einer seltenen Versteinerung aus dem Geschlechte der Gienmuscheln. Physikalische Arbeiten der einträchtigen Freunde in Wien 1(3), 87-89.

HanZlíkovÁ, E. 1962. Poznámky k mikrofaunám klentnických vrstev a ernstbrunnských vápenců v Pavlovských vrších. Zprávy o geologických výzkumech v roce 1961, 204-206.

HanzlíkovÁ, E. 1965. The Foraminifera of the Klentnice Beds (Malm). Sborník geologických věd, Paleontologie 5, 39-106.

Harzhauser, M. \& Schneider, S. accepted. A new family of giant Jurassic-Cretaceous gastropods from the northern Tethys shelf. Acta Palaeontologica Polonica. DOI 10.4202/app.2011.0196

HAUER, F. VON 1869. Geologische Uebersichtskarte der österreichisch-ungarischen Monarchie. Blatt Nr. I und II. Böhmen. Jahrbuch der Kaiserlich-königlichen geologischen Reichsanstalt 19, 1-58.

HaUER, F. von 1875. Die Geologie und ihre Anwendung auf die Kenntniss der Bodenbeschaffenheit der österr.-ungar. Monarchie. 681 pp. Alfred Hölder, Vienna.

HaUER, F. von 1878. Die Geologie und ihre Anwendung auf die Kenntniss der Bodenbeschaffenheit der österr.-ungar. Monarchie. Zweite, vermehrte und verbesserte Auflage. 764 pp. Alfred Hölder, Vienna.

Havír, J. \& STRÁNíK, Z. 2003. Orientations of paleostresses in the Jurassic limestones on the front of the West Carpathian flysch 
nappes; Pavlov Hills, south Moravia. Geologica Carpathica $54,409-416$.

HingENAU, O. vON 1852. Übersicht der geologischen Verhältnisse von Mähren und österr. Schlesien. 82 pp. Carl Herold \& Sohn, Vienna.

HoвzA, P. 1876. Uebersicht der geologischen Verhältnisse von Nikolsburg und Umgebung. Dritter Jahres-Bericht des Staats-Real und Ober-Gymnasiums in Nikolsburg, für das Schuljahr 1876, 3-34.

HoERnES, M. 1874. Versteinerungen aus dem Jurakalk von Nikolsburg. Berichte über die Mitteilungen von Freunden der Naturwissenschaften in Wien 2, 3-5.

Hofmann, T. 1990a. Der Ernstbrunner Kalk im Raum Dörfles (Niederösterreich). Mikrofazies und Kalkalgen. 164 pp. Diploma thesis, University of Vienna, Austria.

Hofmann, T. 1990b. Der Ernstbrunner Kalk (Tithon) im Raum Dörfles (Niederösterreich); Mikrofazies und Kalkalgen. Nachrichten, Deutsche Geologische Gesellschaft 43, 45-46.

Hofmann, T. 1991a. Some aspects on the classification of Salpingoporella pygmaea (calcareous algae, Dasycladaceae). In Kovar-Eder, J. (ed.) Palaeovegetational development of Europe. Pan-European Palaeobotanical Conference, 19.-23. September 1991, Abstract-Volume, Vienna, 15.

HofmAnN, T. 1991b. Observations on Tithonian dasyclad algae of the Ernstbrunn limestone (Lower Austria). In $5^{\text {th }}$ International Symposium on Fossil Algae, Capri, 7.-12. April 1991, Abstracts Volume, Capri, 27.

Hofmann, T. 1992a. Some aspects on the classification of Salpingoporella pygmaea (calcareous algae) from the Ernstbrunn Limestone (Tithonian) of Lower Austria, 281-287. In Kovar-Eder, J. (ed.) Palaeovegetational development in Europe and regions relevant to its palaeofloristic evolution. Proceedings of the Pan-European Palaeobotanical Conference, Vienna, 19-23 September 1991. Natural History Museum, Vienna.

Hofmann, T. 1992b. Excursion II. Mitteilungen der Österreichischen Geologischen Gesellschaft 85, 138-160.

Hofmann, T. 1993a. Jurassic of the Eastern Alps, A2.1-A2.14. In Höfling, R., Moussavian, E. \& Piller, W.E. (eds) Facial development of algae-bearing carbonate sequences in the Eastern Alps: International Symposium Munich - Vienna, $29^{\text {th }}$ August $-5^{\text {th }}$ September 1993. Field Trip Guidebook. Mitteilungen aus dem Paläontologischen Institut der Universität Wien 367.

Hofmann, T. 1993b. Autochthonous Late Jurassic algal associations. Waschberg Zone/Lower Austria, B6.1-B6.7. In HöFLing, R., Moussavian, E. \& Piller, W.E. (eds) Facial development of algae-bearing carbonate sequences in the Eastern Alps: International Symposium Munich - Vienna, $29^{\text {th }}$ August $-5^{\text {th }}$ September 1993. Field Trip Guidebook. Mitteilungen aus dem Paläontologischen Institut der Universität Wien 367.

Hofmann, T. 1994. Chinianella (?) scheympflugi, a new dasyclad alga (green algae) from the Tithonian Ernstbrunn Limestone in Lower Austria. Proceedings of the International Symposium and Field-meeting "Alpine algae 93". Beiträge zur Paläontologie von Österreich 19, 143-147.

Hofmann, T. 1995. Die Tithonklippe von Ernstbrunn, 121-126. In WeIDERT, W.K. (ed.) Klassische Fundstellen der Paläontologie, Band 3. Goldschneck Verlag, Korb.
Hofmann, T. 1997. Bemerkungen zu den Klippen. Exkursionsführer, Österreichische Geologische Gesellschaft 17, $113-116$.

Hofmann, T. 2001. Zum geologisch-paläontologischen Forschungsstand der Ernstbrunner Kalke. In ZeIss, A. Die Ammonitenfauna der Tithonklippen von Ernstbrunn, Niederösterreich. Neue Denkschriften des Naturhistorischen Museums in Wien, Neue Serie 6, 17-26.

Hofmann, T., Švábenická, L. \& HradeckÁ, L. 1999. Biostratigraphy of fissure fillings in the Ernstbrunn Limestone of the Waschberg Zone (Lower Austria). Abhandlungen der Geologischen Bundesanstalt 56, 465-474.

HolzKneCht, M. \& HAMršMíd, B. 1988. Mikrofauna des Malms in der Bohrung Nové Mlýny-3 (Südmähren, Tschechoslowakei). Miscellanea micropalaeontologica 3, 9-72.

HoušA, V. \& ŘEHÁNeK, J. 1987. Poznámky k biostratigrafickému využití mikrofosilií ve svrchní juře a křídě na Moravě. Remarks on the biostratigraphic use of microfossils in the Upper Jurassic and Cretaceous of Moravia. Časopis pro mineralogii a geologii 32, 123-132.

Houša, V., Scheibner, E. \& STRÁNík, Z. 1963. Tithonian stratigraphy of West Carpathians. Geologický sborník 14, 3-17.

JAVORSKIJ, V.I. 1947. Nekotorye paleozojskie i mezozojskie Hydrozoa, Tabulata i Algae. Monografii po paleontologii SSSR 20,1-30.

JENKyns, H.C. 1974. Origin of red nodular limestones (Ammonitico Rosso, Knollenkalke) in the Mediterranean Jurassic: a diagenetic model, 249-271. In Hsü, K.J. \& JENKYns, H.C. (eds) Pelagic sediments on land and under the sea. International Association of Sedimentologists Special Publication 1.

Joukowsky, E. \& FAVRe, J. 1913. Monographie géologique e paléontologique du Salève (Haute-Savoie, France). Mémoires de la Société de Physique et d'Histoire naturelle de Genève 37(4), 295-523.

JÜTTNER, K. 1922. Entstehung und Bau der Pollauer Berge, 6-8. A. Bartosch, Nikolsburg.

JÜTTNER, K. 1930 [for 1927-1929]. Tektonik und geologische Geschichte der Pollauer Berge. Verhandlungen des Naturforschenden Vereines in Brünn 61, 1-19.

JüTTNER, K. 1931. Die Rutschgebiete an den Hängen der Pollauer Berge. Firgenwald 4, 108-121.

JÜTTNER, K. 1932. Klippenbau, Grundwasserverhältnisse und Rutschungen im Gebiete der Pollauer Berge. Firgenwald 5, 80-84.

JÜTTNER, K. 1933a [for 1932]. Zur Stratigraphie und Tektonik des Mesozoikums der Pollauer Berge. Verhandlungen des Naturforschenden Vereines in Brünn 64, 15-31.

JÜTTNER, K. 1933b. Ergebnisse der Diskussion über die Pollauer Berge. Firgenwald 6, 3-8.

JütTNER, K. 1934. Die tektonische Stellung der Pollau-Nikolsburger Jura-Berge. Firgenwald 7, 65-67.

JÜTTNER, K. 1940. Erläuterungen zur Geologischen Karte des unteren Thayalandes. Mitteilungen der Reichsstelle für Bodenforschung Zweigstelle Wien 1, 1-57.

JütTNER, K. 1942. Beiträge zur Geologie des Gebietes der Pollauer Berge. Niederdonau / Natur und Kultur 16. 34 pp. Karl Kühne Verlag, Wien \& Leipzig.

Kamptner, E. 1951. Über das Auftreten der Codiaceen-Gattung Cayeuxia Frollo im Ober-Jura von Ernstbrunn (Niederöster- 
reich). Sitzungsberichte der Österreichischen Akademie der Wissenschaften, Mathematisch-naturwissenschaftliche Klasse, Abteilung I 160(3-4), 177-197.

Kapounek, J., Kröll, A., Papp, A. \& Turnovsky, K. 1967. Der mesozoische Sedimentanteil des Festlandsockels der Böhmischen Masse. Jahrbuch der Geologischen Bundesanstalt 110, 73-91.

KeLLY, S.R.A. 1990. Biostratigraphy of the bivalve Buchia in the Late Jurassic and Early Cretaceous sediments of Europe. Trudy Instituta Geologii i Geofiziki, Akademiya Nauk SSR, Sibirskoe Otdelenie 699, 129-151.

Kober, L. 1926. Geologie der Landschaft um Wien. 150 pp. Julius Springer, Wien.

KoHN, V. 1911. Geologische Beschreibung des Waschbergzuges. Mitteilungen der geologischen Gesellschaft Wien 4, 117-142.

Kolenati, F.A. 1852. Geognostische Karte der Umgebung von Brünn, $1: 20.000$. Brünn. [not seen]

KRAFFT, A. vON 1897. Über einen neuen Fund von Tithon in Niederfellabrunn bei Stockerau. Verhandlungen der Kaiserlich-königlichen geologischen Reichsanstalt 1897, 193-196.

KRÖLL, A. 1980. Die Molassezone Niederösterreichs, 202-212. In Bachmayer, F. (ed.) Erdöl und Erdgas in Österreich. Veröffentlichungen des Naturhistorischen Museums Wien, Neue Folge 19.

KroH, A. 2010. Schatzsuche im Museum. Universum 2010(3), Das Naturhistorische, 10-11.

KüHN, O. 1939. Eine Jurakoralle aus der Klippe von Staatz. Verhandlungen der Zweigstelle Wien der Reichsstelle für Bodenforschung 1939(7-8), 183-185.

KuTEK, J. \& ZeIsS, A. 1988. Further data on the correlation of the Middle/Upper Tithonian with the Lower/Middle Volgian boundary. $2^{\text {nd }}$ international symposium on Jurassic stratigraphy, 623-639.

LADWEIN, H.W. 1976. Sedimentologische Untersuchungen an Karbonatgesteinen des autochthonen Malm in Niederösterreich (Raum Altenmarkt-Staatz). 135 pp. Ph.D. thesis, Universität Innsbruck, Austria. [not seen]

LORIOL, P. DE \& BouRgeAt, E. 1886-1888. Études sur les mollusques des Couches coralligènes de Valfin (Jura). Mémoires de la Société paléontologique Suisse 13-15, 1-369.

Makowsky, A. 1874. Über eine neue fossile Gasteropode „Pterocera gigantea" nova species. Verhandlungen des naturforschenden Vereines Brünn 8, 123-124.

Malzer, O., Rögl, F., Seifert, P., Wagner, L, Wessely, G. \& BRIX, F. 1993. Die Molassezone und deren Untergrund, 281-292. In Brix, F. \& Schultz, O. (eds) Erdöl und Erdgas in Österreich. Naturhistorisches Museum Wien, Wien \& Horn.

MATĚJKA, J. 1926. Jurské vápence moravské a jejich zužitkování. Zprávy Státního výzkumného ústavu pro prưmysl silikátový. [not seen]

MATĚJKA, J. 1929. Jurské vápence z okolí Mikulovna. Zprávy Státního výzkumného ústavu pro průmysl silikátový. [not seen]

MATĚJKA, A. 1963. Mezozoikum a terciér Karpatské soustavy, 104-108. In KALÁŠEK, J. et al. Vysvětlivky k přehledné geologické mapě ČSSR 1:200 000 M-33-XXIX - Brno. Praha.

MatěsKa, A. \& Strání, Z. 1961. Poznámky ke geologii Pavlovských vrchů (List spec. mapy Mikulov - 4457). Zprávy o geologických výzkumech $v$ roce 1960, 153-154.
MatzKa, J. 1934. Die Fossilien der Juraklippen der Pollauer Berge. Ph.D. thesis, Praha. [not seen]

Meyer, H. von 1864. Briefliche Mitteilungen. Notiz über neue Prosoponiden und über Gastrodorus. Neues Jahrbuch für Mineralogie, Geologie und Paläontologie 1864, 206-211.

Mikula, H. 1927. Die Pollauer Berge als Landschaft. Mitteilungen der Geographischen Gesellschaft in Wien 70, 306-327.

MoEller, M. 1911. Die Juraklippen zwischen Donau und Thaya. II. Die Tithonklippen von Ernstbrunn. 1. Cephalopoden und Korallen. 121 pp. Ph.D. thesis, University of Vienna, Austria.

Moericke, W. 1897 [1889]. Die Crustaceen der Stramberger Schichten. Palaeontographica, Supplement 2, Abteilung 6, 43-72.

Moshammer, B. \& Lobitzer, H. 1997. Oberjura-Plattformkarbonate in Österreich: Eine Gegenüberstellung der Ernstbrunner Kalke, Plassenkalke und Sulzfluhkalke in geochemischen und weißmetrischen Analysen. Exkursionsführer, Österreichische Geologische Gesellschaft 17, 57-60.

Moshammer, B. \& Schlagintweit, F. 1999. The Ernstbrunn Limestone (Lower Austria): New data on biostratigraphy and applied geology. Abhandlungen der Geologischen Bundesanstalt 56, 553-565.

Neumayr, M. 1870. Jurastudien. I. Die Klippe von Czetechowitz in Mähren. Jahrbuch der Kaiserlich-königlichen geologischen Reichsanstalt 20, 549-556.

Neumayr, M. 1887. Erdgeschichte. Zweiter Band. Beschreibende Geologie. 879 pp. Verlag des Bibliographischen Institutes, Vienna.

Noth, R. 1951. Foraminiferen aus Unter- und Oberkreide des österreichischen Anteils an Flysch, Helvetikum und Vorlandvorkommen. Jahrbuch der Geologischen Bundesanstalt, Sonderband 3, 1-91.

OBERHAUSER, R. (ed.) 1980. Der geologische Aufbau Österreichs. 700 pp. Springer, Vienna \& New York.

OGG, J.G., OGG, G. \& Gradstein, F.M. 2008. The concise geologic time scale. 177 pp. Cambridge University Press, Cambridge.

PApp, A. \& Turnovsky, K. 1964. Die Ergebnisse der Aufschlußarbeiten der ÖMV AG etc., II. Erdöl-Zeitung 80, 93-99.

PARTSCH, P. 1844. Erläuternde Bemerkungen zur geognostischen Karte des Beckens von Wien und der Gebirge, die dasselbe umgeben. $24 \mathrm{pp}$. Vienna.

PAul, C.M. 1898. Der Wienerwald. Ein Beitrag zur Kenntnis der nordalpinen Flyschbildungen. Jahrbuch der Kaiserlich-königlichen geologischen Reichsanstalt 48, 53-178.

PČelintzev, V. [= Pcelintcev, V.F.] 1924. Description of some Jurassic fauna from the limestones of the Crimea. [Некоторые данные о фауне верхнеюрских извстняков Крыма.] Travaux de la Société des Naturalistes de Leningrad, Section de Géologie et de Minéralogie 54(4), 130-144. [in Russian]

Pčelintzev, V.F. [= Pcelintcev, V.F.] 1963. Gastropods from Mesozoic rocks of Crimea. [Брюхоногие Мезозоя горного Крыма.] Akademiya NAUK SSSR, Geologicheskiy Muzey im. A. P. Karpinskogo, Seriya monograficheskaya 4, 1-74. [in Russian]

Peters, K.F. 1855. Die Nerineen des oberen Jura in Österreich. Sitzungsberichte der mathematisch-naturwissenschaftlichen 
Classe der kaiserlichen Akademie der Wissenschaften 16, 356-366.

Peters, K.F. 1867. Grundlinien zur Geographie und Geologie der Dobrudscha. II. Geologischer Theil. Denkschriften der mathematisch-naturwissenschaftlichen Klasse der Kaiserlichen Akademie der Wissenschaften 27, 145-207.

Petrascheck, W. 1914. Zur Frage des Waschberges und der alpin-karpathischen Klippen. Verhandlungen der Geologischen Reichsanstalt 1914, 146-152.

Petrascheck, W. 1921 [for 1920]. Tektonische Untersuchungen am Alpen- und Karpathenrande. Jahrbuch der Geologischen Staatsanstalt Wien 70, 255-272.

Pícha, F. \& Hanzlíková, E. 1965. Die Juraklippen in der Ždánice-Einheit bei Zaječí. Věstník Ústředního ústavu geologického 40(3), 175-179.

Pícha, F.J., StrÁník, Z. \& Krejčí, O. 2006. Geology and hydrocarbon resources of the outer Western Carpathians and their foreland, Czech Republic. AAPG Memoir 84, 49-175.

Plöchinger, B. \& Karanitsch, P. 2002. Faszination Erdgeschichte mit Brennpunkt Mödling am Alpenostrand. 238 pp. Heimat Verlag, Bruck a. D., Leitha \& Schwarzach.

PoKoRnÝ, V. 1958. K určení stáří křídových uloženin na Pavlovských kopcích. Časopis pro mineralogii a geologii 3(3), 299-315.

PoKoRnÝ, V. 1959. Př́́spěvek mikropaleontologie k řešení tektoniky Pavlovských kopců. Časopis pro mineralogii a geologii 4, 40-46.

Pokorný, V. 1971. Cuvillierella jeani n. gen., n. sp. (Ostracoda, Crustacea) du Jurassique supérieur de la Tchéchoslovaquie. Revue de Micropaléontologie 14(5), 78-82.

PoKoRnÝ, V. 1973. The Ostracoda of the Klentnice Formation (Tithonian?) Czechoslovakia. Rozpravy Ústředního ústavu geologického 40, 1-107.

Poul, I. \& Melichar, R. 2003. Brittle deformation of the Ernstbrunn Limestone (Jurassic) of the Pavlov Hills. Geolines 16, 84-85.

Poul, I. \& Melichar, R. 2005. The new structural model of the Pavlov Hills (Western Carpathians, Czech Republic). Geolines 19, 96.

Poul, I. \& Melichar, R. 2006. Flat-ramp-flat thrust geometry in the external Western Carpathians (Palava Hills, Czech Republic). Volumina Jurassica 4, 62-63.

Poul, I., Melichar, R. \& JANECKÁ, J. 2011. Thrust tectonics of the Upper Jurassic limestones in the Pavlov Hills (outer Western Carpathians, Czech Republic). Geological Society Special Publications 349, 237-248. DOI 10.1144/SP349.13

PreY, S. 1960. Gedanken über Flysch und Klippenzonen in Österreich anläßlich einer Exkursion in die polnischen Karpathen. Verhandlungen der Geologischen Bundesanstalt 1960, 197-214.

PreY, S. 1965. Vergleichende Betrachtungen über Westkarpaten und Ostalpen im Anschluss an Exkursionen in die Westkarpaten. Verhandlungen der Geologischen Bundesanstalt 1965, 65-107.

PrinZINGER, H. 1851. Mittheilung über die Jurakalke in dem nördlich von der Donau gelegenen Theile von NiederOesterreich. Sitzungsbericht. Jahrbuch der Kaiserlich-königlichen geologischen Reichsanstalt 1851(4), 166-168.

Rasumovsky, G. 1830. Einige neue Ansichten über die Österreichischen Alpen. Isis, 143-162. [not seen]
Rasumovsky, G. 1831. Einige neue Ansichten über die Österreichischen Alpen. Neues Jahrbuch für Mineralogie, Geognosie, Geologie und Petrefaktenkunde 2, 210-213.

ŘEHÁNeK, J. 1987a. Faciální vývoj a biostratigrafie ernstbrunnských vápenců (střední - svrchní tithon, jižní Morava). Geologické práce, Správy 87, 27-60.

ŘEHÁNEK, J. 1987b. Biostratigrafie a faciální vývoj karbonátového malmu jv. svahů Českého masívu. Miscellanea micropaleontologica 2(1), 251-282.

RIEDL, H. 1957. Der Karst der Juraklippen in der niederösterreichischen Waschbergzone. Die Höhle 8, 1-9.

RIEDL, H. 1958a. Beiträge zur Morphologie des Gebietes der Waschbergzone. 184 pp. Ph.D. thesis, University of Vienna, Austria. [not seen]

RiEDL, H. 1958b. Die Verkarstung des mesozoischen Bereiches der niederösterreichischen Waschbergzone (Leiser Berge). II. Bericht. Die Höhle 9, 80-84.

RIEDL, H. 1960. Beiträge zur Morphologie des Gebietes der Leiser Berge und des Falkensteiner Höhenzuges. Mitteilungen der Österreichischen Geographischen Gesellschaft 102, 65-76.

Roberts, C.M., Mc Clean, C.J., Veron, J.E.N., Hawkins, J.P., Allen, G.R., McAllister, D.E., Mittermeier, C.G., Schueler, F.W., Spalding, M., Wells, F., Vynne, C. \& WerNER, T.B. 2002. Marine biodiversity hotspots and conservation priorities for tropical reefs. Science 295, 1280-1284. DOI 10.1126/science. 1067728

Robins, C.M., Feldmann, R.M. \& Schweitzer, C.E. 2007. Primitive brachyurans and galatheids from Ernstbrunn, Austria; an evaluation of the Friedrich Bachmayer collection. Memorie della Società Italiana di Scienze Naturali e del Museo Civico di Storia Naturale di Milano 35, 85-86.

Robins, C.M., Feldmann, R.M. \& Schweitzer, C.E. 2010. Systematizing typical ornamentation and groove structures of Late Jurassic galatheids (Decapoda, Galatheoidea). Abstracts with Programs - Geological Society of America 42, 84.

Robins, C.M., Feldmann, R.M. \& Schweitzer, C.E. 2012. The oldest Munididae (Decapoda: Anomura: Galatheoidea) from Ernstbrunn, Austria (Tithonian). Annalen des Naturhistorischen Museums Wien, Serie A 114, 289-300.

Robins, C.M., Feldmann, R.M. \& Schweitzer, C.E. 2013. Nine new genera and 24 new species of the Munidopsidae (Decapoda: Anomura: Galatheoidea) from the Jurassic Ernstbrunn Limestone of Austria, and notes on fossil munidopsid classification. Annalen des Naturhistorischen Museums in Wien, Serie A 115, 167-251.

Rögl, F., KroH, A., Hofmann, T. \& Zuschin, M. 2009. Exkursion Waschbergzone. 15. Jahrestagung der Österreichischen Paläontologischen Gesellschaft, Stetten (09.-10.10.2009). Berichte der Geologischen Bundesanstalt 81, 32-49.

Roetzel, R. 2002. Waschbergzone, Steinitzer Einheit, Pausramer Einheit, 29-30. In SchnABel, W. (ed.) Geologische Karte von Niederösterreich $1: 200.000$. Legende und kurze Erläuterung. Geologische Bundesanstalt, Land Niederösterreich, Vienna.

Rohatsch, A. \& Thinschmidt, A. 1997. Charakterisierung und Vorkommen historisch bedeutsamer Baugesteine im nördlichen Weinviertel - eine Auswahl. Exkursionsführer, Österreichische Geologische Gesellschaft 17, 45-52. 
Rolle, F. 1855. Die Echinoiden der oberen Juraschichten von Nikolsburg in Mähren. Sitzungsberichte der Kaiserlichen Akademie der Wissenschaften, Mathematisch-naturwissenschaftliche Klasse 15, 521-540.

Rотн, Z. 1962. K problémům oblasti flyše v Čs. Karpatech. Geologické práce, Zošity 63, 5-13.

Rотн, Z. 1967. Die strukturellen Beziehungen in der Grenzzone zwischen den Alpen und den Karpaten. Geologické práce, Zprávy 42, 29-49.

Roтн, Z. 1980. Západní Karpaty - terciérní struktura střední Evropy. Knihovna Ústředního ústavu geologického 55, 1-128.

Roth, Z. \& HanzlíkovÁ, E. 1968. The western part of the WestCarpathian Flysch Belt. Stratigraphy, 374-430. In MATĚJKA, A. (ed.) Regional geology of Czechoslovakia, Part 2, The West Carpathians. Geological Survey of Czechoslovakia, Praha.

RzeHAK, A. 1902-1903. Die Tertiärformation in der Umgebung von Nikolsburg in Mähren. Zeitschrift des Mährischen Landesmuseums 2, 28-61 and 3, 53-79.

Sauer, R., Seifert, P. \& Wessely, G. 1992. Guidebook to excursions in the Vienna Basin and adjacent Alpine-Carpathian thrustbelt in Austria. Mitteilungen der Österreichischen Geologischen Gesellschaft 85, 1-264.

SCHILLER, J. 1930. Coccolithineae, 89-267. In RABENHORST, L. (ed.) Kryptogamen-Flora 10. Akademie Verlag, Leipzig.

Schlagintweit, F. 2011. Morphological specification of Chinianella scheympflugi Hofmann, 1994, a Late Jurassic (?Earliest Cretaceous) dasycladalean alga of the western Tethyan domain. Studia Universitatis Babes-Bolyai, Geologia 56, 3-9.

Schlotheim, E.F. von 1820. Die Petrefactenkunde auf ihrem jetztigen Standpunkte durch die Beschreibung seiner Sammlung versteinerter und fossiler Überreste des Thier- und Pflanzenreichs der Vorwelt. 1xii + 437 pp. Becker'sche Buchhandlung, Gotha.

SCHNABel, E. 1929. Zur Geologie des Thayagebietes. Petroleum $32,1097-1100$.

Schnabel, E. 1933a. Pavlovské kopce. Příroda 26, 12-16. [not seen]

SCHNABEL, E. 1933b. Závěr k poznámkám J. Stejskala ke geologii Pavlovských kopců. Přiroda 26, 97-98. [not seen]

Schnabel, W. (ed.) 2002. Geologische Karte von Niederösterreich 1 : 200.000. Legende und kurze Erläuterung. 45 pp. Geologische Bundesanstalt, Land Niederösterreich, Vienna.

SchNeIDER, S. 2012. Muscheln aus der Weinviertler Lagune. Universum 2012(3), 64-65.

Schneider, S., Harzhauser, M., Kroh, A., Lukeneder, A. \& Zuschin, M. 2011. The horns from Ernstbrunn - Composition and palaeoecology of a Tithonian reef-associated lagoonal bivalve community. 82. Jahrestagung der Paläontologischen Gesellschaft, abstract volume. Beiträge zur Paläontologie 32, 33.

SchöN, H. 1927 [for 1925-1926]. Zur Tektonik der Pollauer Berge. Verhandlungen des Naturforschenden Vereines in Brünn 60, 59-67.

SchudACK, M.E. \& Schudack, U. 1997. Biostratigraphische und biogeographische Beziehungen der süddeutschen OberjuraOstracoden: Parallelen zu paläogeographischen und paläoklimatischen Entwicklungen. Geologische Blätter für Nordost-Bayern 47, 99-116.
Schweitzer, C.E. \& Feldmann, R.M. 2008a [printed for 2007]. A new classification for some Jurassic Brachyura (Crustacea: Decapoda: Brachyura: Homolodromioidea): families Goniodromitidae Beurlen, 1932 and Tanidromitidae new family. Senckenbergiana lethaea 87, 119-156.

Schweitzer, C.E. \& Feldmann, R.M. 2008b. Revision of the genus Laeviprosopon Glaessner, 1933 (Decapoda: Brachyura: Homolodromioidea: Prosopidae) including two new species. Neues Jahrbuch für Geologie und Paläontologie, Abhandlungen 250, 273-285.

DOI $10.1127 / 0077-7749 / 2008 / 0250-0273$

Schweitzer, C.E. \& Feldmann, R.M. 2009a. Revision of the Prosopinae sensu Glaessner, 1969 (Crustacea: Decapoda: Brachyura) including four new families, four new genera, and five new species. Annalen des Naturhistorischen Museums Wien, Serie A 110, 55-121.

Schweitzer, C.E. \& Feldmann, R.M. 2009b. New species of Longodromitidae Schweitzer and Feldmann, 2009, from the Ernstbrunn Formation, Late Jurassic (Tithonian), Austria. Annalen des Naturhistorischen Museums Wien, Serie A 111, 207-224.

Schweitzer, C.E. \& Feldmann, R.M. 2009c. Revision of Gabriella Collins et al., 2006 (Decapoda: Brachyura: Homolodromioidea: Tanidromitidae) with new Jurassic species. Neues Jahrbuch für Geologie und Paläontologie, Abhandlungen 252, 1-16. DOI 10.1127/0077-7749/2009/0252-0001

Schweitzer, C.E. \& Feldmann, R.M. 2009d. Revision of the genus Cyclothyreus Remes, 1895 (Decapoda: Brachyura: Dromioidea). Neues Jahrbuch für Geologie und Paläontologie, Abhandlungen 253, 357-372.

DOI 10.1127/0077-7749/2009/0253-0357

Schweitzer, C.E. \& Feldmann, R.M. 2010a. A new family of Mesozoic Brachyura (Glaessneropsoidea) and reevaluation of Distefania Checchia-Rispoli, 1917 (Homolodromioidea: Goniodromitidae). Neues Jahrbuch für Geologie und Paläontologie, Abhandlungen 256, 363-380.

DOI 10.1127/0077-7749/2010/0059

Schweitzer, C.E. \& Feldmann, R.M. 2010b. Revision of Cycloprosopon and additional notes on Eodromites (Brachyura: Homolodromioidea: Goniodromitidae). Annalen des Naturhistorischen Museums Wien, Serie A 112, 169-194.

Schweitzer, C.E. \& Feldmann, R.M. 2010c. The genus Coelopus Etallon, 1861 (Brachyura: Glaessneropsoidea: Longodromitidae) with new species. Neues Jahrbuch für Geologie und Paläontologie, Abhandlungen 258, 51-60.

DOI 10.1127/0077-7749/2010/0084

Schweitzer, C.E. \& Feldmann, R.M. 2010d. Earliest known Porcellanidae (Decapoda: Anomura: Galatheoidea) (Jurassic: Tithonian). Neues Jahrbuch für Geologie und Paläontologie, Abhandlungen 258, 243-248. DOI 10.1127/0077-7749/2010/0096

SeIFERT, P. 1993. Die Waschbergzone, 358-359. In BrIX, F. \& Schultz, O. (eds) Erdöl und Erdgas in Österreich. Naturhistorisches Museum Wien, Vienna, Horn.

Spath, L.F. 1933. Revision of the Jurassic cephalopod fauna of Kachh (Cutch). Part VI. Palaeontologia Indica, New Series 9(2), VII + 659-945.

StejSKal, J. 1928. „Popelový vršek“ u Klentnice v Pavlovských vrších. Př́roda 21, 50-53. [not seen] 
StejSKal, J. 1930. Svážná území na Pavlovských vrších. Věstník Československé akademie zemédělské 6(5), 483-486. [not seen]

StejSKAL, J. 1931. Svážná území na Pavlovských vrších. Sborník Československé akademie zemědělské, oddíl A 6, 55-94. [not seen]

SteJSKAL, J. 1932. Zur Frage der Rutschungen an den Hängen der Pollauer Berge. Firgenwald 5, 38-43.

Stejskal, J. 1935a. Geologická stavba Pavlovských vrchů na již. Moravě. I. Stratigrafie. La géologie des Pavlovské vrchy (,Pollauer Berge“) dans la Moravie du Sud. I. La stratigraphie. Věstník Ústředního ústavu geologického 10, 199-209.

Stejskal, J. 1935b. Geologická stavba Pavlovských vrchů se zřetelem na stratigrafii a tektoniku flyše. Část 2. La géologie des Pavlovské vrchy („Pollauer Berge“). 2ème partie. Věstník Ústředního ústavu geologického 11, 15-32.

Stojaspal, F. 1984. Erdgeschichtliches aus dem Bezirk Korneuburg. I. Das Korallenriff von Ernstbrunn. Korneuburger Kulturnachrichten 1984(1), 2-7.

StRadNeR, H. 1961. Vorkommen von Nannofossilien im Mesozoikum und Alttertiär. Erdöl-Zeitschrift 1961, 77-88.

STRÁNík, Z., AdÁMEK, J. \& CipRYs, V. 1979. Geologický profil karpatskou předhlubní, flyšovým pásmem a vídeňskou pánví v oblasti Pavlovských vrchů, 7-13. In MAHEL, M. (ed.) Tektonické profily Západných Karpát. Tectonic profiles through the West Carpathians. Geologický ústav Dionýza Sútra, Bratislava.

Strání, Z., ČtYroký, P. \& Havlíček, P. 1999. Geologická minulost Pavlovských vrchů. Die geologische Vergangenheit der Pollauer Berge. Sborník geologických věd, Geologie 49, $5-32$.

SuESS, E. 1852. Mittheilung zur Lage von Sandsteinen und sandigen Mergeln, die in der Gegend von Nikolsburg anstehen. Jahrbuch der Kaiserlich-königlichen geologischen Reichsanstalt 3(4), 129.

SuEss, E. 1858. Die Brachiopoden der Stramberger Schichten. Beiträge zur Palaeontographie von Oesterreich 1, 15-58.

SuESs, E. 1885. Das Antlitz der Erde. Erster Band. 778 pp. F. Tempsky, G. Freytag, Praha \& Leipzig.

SuEss, E. 1929. Grundsätzliches zur Entstehung der Landschaft von Wien. Zeitschrift der Deutschen Geologischen Gesellschaft 81, 177-236.

Tercier, J. 1936. Sur l'extension de la zone ultrahelvétique en Autriche. Eclogae geologicae Helvetiae 29, 213-250.

ThenIUs, E. 1974. Geologie der Österreichischen Bundesländer in kurzgefassten Einzeldarstellungen. Niederösterreich. 280 pp. Geologische Bundesanstalt, Vienna.

Thenius, E. \& Vavra, N. 1996. Fossilien in Volksglauben und Alltag. 179 pp. Schweizerbart, Stuttgart.

Tollmann, A. 1963. Die Faziesverhältnisse im Mesozoikum des Molasseuntergrundes der West- und Ostalpen. Erdöl-Zeitung $79,41-52$.

Tollmann, A. 1966. Die alpidischen Gebirgsbildungs-Phasen in den Ostalpen und Westkarpaten. Geotektonische Forschungen 21, 1-156.

Tollmann, A. 1971. Der karpatische Einfluß am Ostrand der Alpen. Mitteilungen der Geologischen Gesellschaft Wien 64, 173-208.

Tollmann, A. 1985. Geologie von Österreich, Band 2. 710 pp. F. Deuticke, Vienna.
Trauth, F. 1948. Die fazielle Ausbildung und Gliederung des Oberjura in den nördlichen Ostalpen. Verhandlungen der Geologischen Bundesanstalt 1948, 145-218.

Uhlig, V. 1903. Bau und Bild der Karpathen, 651-911. In Diener, C., Hoernes, R., Suess, F.E. \& Uhlig, V. Bau und Bild Österreichs. Tempsky, Freytag, Vienna \& Leipzig.

Uhlig, V. 1904. Über die Klippen der Karpaten. Comptes Rendus IX. Congrès géologique international de Vienne 1903, 427-454. Hollinek, Vienna.

Uhlig, V. 1907. Über die Tektonik der Karpathen. Sitzungsberichte der Kaiserlichen Akademie der Wissenschaften in Wien, Mathematisch-naturwissenschaftliche Klasse 116, Abteilung I, 871-982.

VAŠIČEK, Z. 1971. Die makropaläontologische Untersuchung von Bohrkernen aus dem Mesozoikum des Untergrundes in Südmähren. Věstník Ústředního ústavu geologického 46(2), 83-91.

VAŠÍČEK, Z. 1980 [for 1978]. Beitrag zur Biostratigraphie des autochthonen Malms in südöstlichen Abhängen der Böhmischen Masse. Sborník vědeckých prací Vysoké školy báňské v Ostravě, Řada hornicko-geologická 24, 29-46.

VAŠíčEK, Z. \& SKUPIEN, P. 2004. Historie geologických a paleontologických výzkumů svrchnojurských a spodnokřídových sedimentů na Štramberku. The Štramberk fossil site (Uppermost Jurassic/Lower Cretaceous, Outer Western Carpathians) - Two centuries of the geological and paleontological research. Sborník vědeckých prací Vysoké školy báňské v Ostravě, Řada hornicko-geologická 50, 83-100.

VAŠÍČEK, Z. \& SKUPIEN, P. 2005. Doplňky k historii geologických a paleontologických výzkumů na Štramberku. Supplements to history of geological and paleontological research of Štramberk territory. Sborník vědeckých prací Vysoké školy báňské v Ostravě, R̆ada hornicko-geologická 51, 1-6.

Vetters, H. 1905. Die Fauna der Juraklippen zwischen Donau und Thaya. I. Teil. Die Tithonklippen von Nieder-Fellabrunn. Beiträge zur Paläontologie und Geologie Österreich-Ungarns und des Orients 17, 223-259.

VetTERs, H. 1910. Die geologischen Verhältnisse der weiteren Umgebung Wiens und Erläuterungen zur geologisch-tektonischen Uebersichtskarte des Wiener Beckens und seiner Randgebirge im Maßstabe 1 : 100.000. 106 pp. Oesterreichische Lehrmittel-Anstalt, Vienna.

WAGner, A. 1863. Monographie der fossilen Fische aus den lithographischen Schiefern Bayerns. Zweite Abtheilung. Abhandlungen der Königlich Bayerischen Akademie der Wissenschaften, Mathematisch-physikalische Klasse 9, 611-748.

Wehner, G. 1988. Über die Prosopiden (Crustacea, Decapoda) des Jura. 154 pp. Ph.D. thesis, Fakultät für Geowissenschaften, Ludwig-Maximilians-Universität München, $\mathrm{Mu}-$ nich, Germany.

Wessely, G. 1993. Das autochthone Stockwerk unter dem Wiener Becken, 276-280. In BRIX, F. \& Schultz, O. (eds) Erdöl und Erdgas in Österreich. Naturhistorisches Museum Wien, Vienna \& Horn.

Wessely, G. 1997. Das autochthone Mesozoikum im weiteren und engeren Raum von Laa an der Thaya. Exkursionsführer, Österreichische Geologische Gesellschaft 17, 53-56.

Wessely, G. 2006. Geologie der österreichischen Bundeslän- 
der - Niederösterreich. 416 pp. Geologische Bundesanstalt, Vienna.

Wessely, G. \& Hofmann, T. 2007. Staatzer Klippe: Hochgeschürfter Molasseuntergrund. In Hofmann, T. (ed.) Wien. Niederösterreich. Burgenland. Wanderungen in die Erdgeschichte 22, 98-99.

WieczoreK, J. 1998. Nerineaceans from the Ernstbrunn Limestone (Tithonian, Austria). Annalen des Naturhistorischen Museums Wien, Serie A 99, 311-329.

ZAPFE, H. 1963. Das Mesozoikum in Österreich. Mitteilungen der Geologischen Gesellschaft in Wien 56, 361-399.

Zapletal, K. 1930. Überblick über die Geologie der tschechoslowakischen Karpathen. Geologische Rundschau 21, 124-140. DOI 10.1007/BF01802269

ZeIss, A. 1977. Some ammonites of the Klentnice Beds (Upper Tithonian) and some remarks on correlation of the uppermost Jurassic. Acta Geologica Polonica 27, 369-386.

ZeIss, A. 1999. The Upper Jurassic ammonite fauna of Ernstbrunn (NE Austria) and its interesting position between the tethydian and subboreal faunas. Berichte der Geologischen Bundesanstalt 46, 127.
ZeIss, A. 2001. Die Ammonitenfauna der Tithonklippen von Ernstbrunn, Niederösterreich. Neue Denkschriften des Naturhistorischen Museums in Wien, Neue Serie 6, 1-117.

Zeiss, A. \& BACHMAYER, F. 1989. Zum Alter der Ernstbrunner Kalke (Tithon, Niederösterreich) (Vorläufige Mitteilung). Annalen des Naturhistorischen Museums Wien, Serie A 90, 103-109.

Zimmer, W. \& Wessely, G. 1996. Exploration results in thrust and subthrust complexes in the Alps and below the Vienna Basin in Austria, 81-107. In Wessely, G. \& Liebl, W. (eds) Oil and gas in Alpidic thrustbelts and basins of central and eastern Europe. EAGE Special Publication 5.

ZitTel, K.A. von 1868. Palaeontologische Studien über die Grenzschichten der Jura- und Kreide-Formation im Gebiete der Karpathen, Alpen und Apenninen. I. Abtheilung. Die Cephalopoden der Stramberger Schichten. Palaeontographica, Supplement 2(1-2), 1-118.

ZitTel, K.A. von 1873. Palaeontologische Studien über die Grenzschichten der Jura- und Kreide-Formation im Gebiete der Karpathen, Alpen und Apenninen. III. Abtheilung. Die Gastropoden der Stramberger Schichten. Palaeontographica, Supplement 2(3), 311-491. 